medRxiv preprint doi: https://doi.org/10.1101/2021.11.24.21266833; this version posted November 26,2021 . The copyright holder for this preprint (which was not certified by peer review) is the author/funder, who has granted medRxiv a license to display the preprint in It is made available under a CC-BY-NC 4.0 International license .

\title{
Large-scale seroepidemiology identifies a nephro-vascular syndrome associated with autoimmune reactivity to tau
}

Andreia D. Magalhães*, Marc Emmenegger*, Elena De Cecco, Manfredi Carta, Karl Frontzek, Andra Chincisan, Simone Hornemann, Adriano Aguzzi

Institute of Neuropathology, University of Zurich, $\mathrm{CH}-8091$ Zurich, Switzerland

Correspondence should be addressed to adriano.aguzzi@usz.ch or simone.hornemann@usz.ch

\section{Abstract}

The microtubule-associated protein tau is involved in several neurodegenerative diseases and is currently being investigated as a plasma biomarker for the detection and monitoring of Alzheimer's disease and as an immunotherapeutical target in clinical trials. We assessed plasma anti-tau IgG reactivity in 40'098 unselected patients visiting a university hospital and healthy blood donors. We found that $4.97 \%$ patients and $1.58 \%$ healthy donors had natural anti-tau antibody titers $>1.8 \log _{10}\left(E C_{50}\right)$. In a multivariate model, female sex $(P<0.001)$, age $(\mathrm{P}<0.001)$, cystitis ( $R R 1.59,95 \% \mathrm{Cl} 1.14-2.16, \mathrm{P}=0.004)$, other urinary disorders (RR 1.23, $95 \% \mathrm{Cl}$ 1.03-1.45, $\mathrm{P}=0.018$ ), chronic kidney disease ( $\mathrm{RR} 1.20,95 \% \mathrm{Cl} 1.01-1.41, \mathrm{P}=0.033$ ), arterial embolism and thrombosis ( $\mathrm{RR} 1.56,95 \% \mathrm{Cl} 1.02-2.25, \mathrm{P}=0.026)$ and atherosclerosis ( $R R$ 1.35, $95 \% \mathrm{Cl} 1.09-1.1 .66, \quad \mathrm{P}=0.004)$ were independent predictors of anti-tau autoantibodies. We therefore conclude that anti-tau autoimmunity is associated with a systemic syndrome that includes vascular, kidney and urinary disorders. The expression of tau in these extraneural tissues suggests a potential role of autoimmunity in this syndrome. 
medRxiv preprint doi: https://doi.org/10.1101/2021.11.24.21266833; this version posted November 26, 2021. The copyright holder for this preprint (which was not certified by peer review) is the author/funder, who has granted medRxiv a license to display the preprint in It is made available under a CC-BY-NC 4.0 International license .

\section{Introduction}

Tau is a microtubule binding protein expressed in neurons $[1,2]$ with a physiological role in cytoskeletal dynamics. Furthermore, tau plays a pivotal role in a variety of neurodegenerative diseases, including Alzheimer's disease (AD) [3], progressive supranuclear palsy, and several syndromes collectively referred to as tauopathies [4]. The presence of intraneuronal tau aggregates (tangles) correlates with cognitive decline $[5,6]$, and plasma measurements of total and phosphorylated tau have emerged as a potential biomarkers for the detection and monitoring of $A D$ progression [7-15]. Active immunization [16] and transfer of antibodies against a wide range of tau epitopes [17] can reduce pathology and functional decline in animal models of tauopathies. These approaches are currently being tested in clinical trials of neurodegenerative diseases [18].

In rare cases, humans can develop antibodies directed against neural proteins. While the outcome of such autoimmunity can be debilitating [19], some autoantibodies may occur physiologically and may even exert neuroprotective effects [20]. Indeed, anti-tau antibodies that have been recovered from humans have been suggested to have diagnostic and therapeutic potential [21-23] and have entered clinical trials [24].

Natural autoantibodies are immunoglobulins generated against self-antigens in the absence of external antigen stimulation $[25,26]$. These natural autoantibodies are a normal part of the immunoglobulin repertoire and may have physiological roles in homeostasis and surveillance, by clearance of cell debris, anti-inflammatory activity, and first line defense against pathogens [27]. Altered levels of natural autoantibodies against various targets were described in various clinical situations such as cancer and neurodegeneration [26]. Natural anti-tau autoantibodies have been detected in sera and plasma of AD patients, Parkinson's disease patients, but also in non-neurodegeneration controls [28-30]. Their effects, if any, are unknown [31]. A comprehensive assessment of natural anti-tau autoantibodies and their associations with the nervous system and systemic diseases could help to clarify the source and function of these autoantibodies and uncover potential biomarkers of disease.

In order to study the prevalence of anti-tau antibodies in humans, we designed a two-sites cross-sectional study and tested $>40,000$ individual plasma samples from healthy blood donors and from patients admitted to a university hospital. We then explored associations with a wide range of diseases based on diagnostic codes and changes in clinical laboratory 
medRxiv preprint doi: https://doi.org/10.1101/2021.11.24.21266833; this version posted November 26, 2021. The copyright holder for this preprint (which was not certified by peer review) is the author/funder, who has granted medRxiv a license to display the preprint in It is made available under a CC-BY-NC 4.0 International license .

parameters. We found a previously unrecognized association between anti-tau autoimmunity and a cluster of systemic disorders that includes vascular, kidney and urinary tract diseases. 
medRxiv preprint doi: https://doi.org/10.1101/2021.11.24.21266833; this version posted November 26, 2021. The copyright holder for this preprint (which was not certified by peer review) is the author/funder, who has granted medRxiv a license to display the preprint in It is made available under a CC-BY-NC 4.0 International license.

\section{Results}

Prevalence of naturally occurring plasma anti-tau autoantibodies in large hospital and blood donor populations

We performed a cross-sectional study with the aim of studying naturally occurring microtubule binding domain of tau protein (MTBD-tau) IgG autoantibodies in two different cohorts. Plasma samples of $31^{\prime} 892$ patients (age $\geq 18$ years) from an unselected university hospital cohort and of 8'206 healthy blood donors were screened for anti-tau plasma IgG autoantibodies by miniaturized ELISA (Enzyme-Linked Immunosorbent Assay) using an automated high-throughput screening (HTS) platform. Samples were tested individually in eight consecutive 2 -fold dilution points (1:50 to 1:6'000). Optical-density readings were fitted to a logistic regression model, and antibody titers were defined as the $-\log _{10}\left(E_{50}\right)$ values (inflexion point of the regression curve).

After exclusion of non-informative samples (due to high background or poor regression coefficient), 23'181 patient samples and 6'590 healthy blood donor samples were included in the analysis (Figure 1A). Positive samples (henceforth termed $\tau^{+}$) were defined as samples with a titer of $-\log _{10}\left(E C_{50}\right) \geq 1.8$. Of the $23^{\prime} 181$ patient samples, $1^{\prime} 152$ were $\tau^{+}(4.97 \%)$ (Figure $1 \mathrm{~A}$ and $1 \mathrm{~B}$ ). Of the $6^{\prime} 590$ healthy donors, only 104 (1.58\%) were $\tau^{+}$(Figure $1 \mathrm{C}$ ), a positivity rate that is lower $(p<0.001)$ than for the hospital patients. Of $6^{\prime} 590$ healthy donors, demographic data was available for 4'157 donors. The median age for the healthy donors group was 42 years-old, significantly lower than the median age of university hospital patients $(P<0.001)$. Moreover, the healthy donors group had less women than the university hospital group $(P<0.001)$. Therefore, we used a multivariate log-binomial regression model with age and sex to estimate the risk ratio for the presence of anti-tau autoantibodies. University hospital patients had 2.37 times the risk of healthy donors to be $\tau^{+}$(RR $2.37,95 \%$ confidence interval (CI) 1.89-3.02, $\mathrm{P}<0.001$ ) (Figure 1D).

The replicability of the microELISA screen was evaluated by testing 308 samples as duplicates. The screen had a high overall replicability $(r=0.919, P<0.001$, Figure $1 \mathrm{E})$. To estimate nonspecific positivity due to cross-reactivity with other nervous-system proteins, we investigated the reactivity of samples to two other proteins implicated in neurodegeneration, amyloid-ß pyroglutamate and the cellular prion protein ( $\left.\operatorname{PrP}^{C}\right)$. We analyzed 12'297 patient samples for their reactivity to MTBD-tau and amyloid-ß pyroglutamate (Figure 1F) and 13'099 
medRxiv preprint doi: https://doi.org/10.1101/2021.11.24.21266833; this version posted November 26,2021 . The copyright holder for this preprint (which was not certified by peer review) is the author/funder, who has granted medRxiv a license to display the preprint in It is made available under a CC-BY-NC 4.0 International license .

patient samples for MTBD-tau and $\operatorname{PrP}^{C}$ (Figure 1G) [32]. $\tau^{+}$samples showed no reactivity against amyloid- $ß$ pyroglutamate or $\operatorname{PrP}^{\mathrm{C}}\left(\mathrm{n}=654 \mathrm{\tau}^{+}\right.$samples for amyloid- $\beta$ pyroglutamate and $\mathrm{n}=694 \mathrm{\tau}^{+}$samples for $\mathrm{PrPC}^{\mathrm{C}}$ ), confirming that anti-tau autoimmunity is specific.

\section{Validation and characterization of positive samples}

Anti-tau antibodies were purified by affinity chromatography from $4 \tau^{+}$plasma samples, and their specificity was tested by competition immunoassay with MTBD-tau (Figure 2A). Antibodies were pre-incubated with either recombinant MTBD-tau, a pool of eight synthetic peptides covering the sequence of MTBD-tau, a synthetic 25-meric peptide derived from TREM2 (Triggering Receptor Expressed On Myeloid Cells 2), or albumin. These antibodyantigen mixtures were then tested by ELISA using microplates coated with MTBD-tau. Preincubation with MTBD-tau and pooled MTBD-tau peptides, but not with the TREM2 peptide or albumin, decreased the ELISA signal in a concentration-dependent manner (Figure 2A). These results confirm the specificity of binding of antibodies from $\tau^{+}$plasma to bona fide tau. Next, we investigated possible polyreactivities of $\tau^{+}$plasma samples by performing indirect ELISA assays with a variety of antigens, including albumin, cardiolipin, DNA, insulin, lipopolysaccharides (LPS) and uncoated plates (Figure 2B). Purified anti-tau autoantibodies were only reactive against MTBD-tau (Figure 2B), and showed specific binding to EGFPON4Rtau-transfected SH-SY5Y cells but not to untransfected cells (Figure 2C). Western blot analysis confirmed the presence of MTBD-tau in cell lysates of tau-expressing SH-SY5Y cells but not in lysates of wild-type SH-SY5Y cells (Figure 2D and Figure S1). These data provide additional confidence that the immunoreactivity of $\tau^{+}$plasma was highly specific for MTBDtau.

\section{Subclass and epitope profiling of $\tau^{+}$autoimmunity}

We further investigated the subclass composition of immunoglobulin heavy and light chains of $\tau^{+}$sera (Figure S2). All four IgG subclasses were found, with IgG1 being the most abundant subclass (Figure S2A and S2B). Both kappa and lambda light chains were also found, with kappa light chain being the most common (Figure S2C and S2D). Three samples were polytypic for kappa and lambda (Figure S2D).

Furthermore, we profiled the epitopes recognized by the $\tau^{+}$sera using a library of 8 synthetic 25-meric peptides overlapping with each other by 10 residues and covering the sequence of MTBD-tau. Most samples showed reactivity to peptides 3 (10 out of 13) and 5 (9 out of 13) 
medRxiv preprint doi: https://doi.org/10.1101/2021.11.24.21266833; this version posted November 26,2021 . The copyright holder for this preprint (which was not certified by peer review) is the author/funder, who has granted medRxiv a license to display the preprint in It is made available under a CC-BY-NC 4.0 International license .

corresponding to the repeat regions 2 and 3 of MTBD-tau (Figure S2E-G). Both light chain typing as well as epitope mapping point towards a polyclonal antibody response, observed in at least 8 of 13 samples (Figure S2D and S2F).

\section{Demographic characteristics of tau-immunoreactive patients}

We performed univariate logistic regression analyses of basic demographic data available in the hospital registry for the $23^{\prime} 181$ samples included in the primary screen. We found that the age of $\tau^{+}$patients (median: 58 years; IQR: 43-71) was higher than that of negatives (median: 55; IQR: 40-69; P < 0.001) (Figure 3A and Table S1), with the percentage of positives increasing with age $(P<0.001)$ (Figure 3B). A log-binomial regression model $[33,34]$ estimated that the risk ratio for the presence of anti-tau autoantibodies was highest for patients aged 70-99 years (RR 1.27, 95\% confidence interval (Cl) 1.12-1.44, $\mathrm{P}<0.001$ ) (Figure 3C) and for women (RR 1.19, 95\% Cl 1.07-1.34, $\mathrm{P}=0.010$ ) (Figure 3C). Due to the association of anti-tau autoantibodies with increased age and female sex, all further estimates of risk ratios were calculated using a multivariate log-binomial regression model with age and sex [age-and-sex adjusted risk ratio $(\mathrm{aRR})]$.

We next investigated a possible association between $\tau^{+}$samples and admission to different clinical departments, as this might inform on potential associations with specific diseases. The highest age-and-gender adjusted risk ratios for positives were found for patients from the department of nephrology (Figure 3D and 3E). No significant difference was found between the percentage of positive and negative patients from the department of neurology (Table S1).

\section{Anti-tau autoantibodies in neurological disorders}

We next explored the clinical data pertaining to diagnoses of diseases available from the hospital registry as ICD-10 (International Classification of Disease and Related Health Problems, $10^{\text {th }}$ revision) codes for $21^{\prime} 995$ patients (Figure $1 \mathrm{~A}$ ). Due to the known role of tau in neurodegenerative disease [3], we first used clinical data to analyze the association between anti-tau autoantibodies and neurological disorders, categorized in 12 main groups of diseases. No association between positive samples and neurological diseases was found (Figure 4A). To further verify this finding, we performed a targeted-screen with 47 samples from Alzheimer's disease (AD) patients and 68 from similarly aged non-AD patients selected from our plasma biobank (Table S2). Samples were screened for MTBD-tau IgG 
medRxiv preprint doi: https://doi.org/10.1101/2021.11.24.21266833; this version posted November 26, 2021. The copyright holder for this preprint (which was not certified by peer review) is the author/funder, who has granted medRxiv a license to display the preprint in It is made available under a CC-BY-NC 4.0 International license.

autoantibodies as in the primary screen, and also for MTBD-tau IgA autoantibodies and fulllength tau IgG and IgA antibodies. No significant difference was observed in the reactivity of $A D$ and control patients' plasma (Figure $4 B$ and $4 C$ ), supporting the hypothesis that the presence of autoantibodies directed against the tested microtubule-binding domain of tau protein is unrelated to $A D$ or other neurological disorders.

\section{Anti-tau autoantibodies in systemic diseases}

We next investigated a possible association between tau autoimmunity and systemic diseases, which were grouped in 14 main systemic disorders (Figure 5A). The risk for tau autoreactivity was highest in patients with vascular disease (aRR $1.46,95 \% \mathrm{Cl} 1.22-1.68$, $\mathrm{P}<0.001$ ), kidney disease (aRR 1.32, 95\% Cl 1.13-1.53, $\mathrm{P}=0.004$ ), and diabetes (aRR $1.28,95 \% \mathrm{Cl}$ 1.09-1.51, P=0.038) (Figure 5A). Importantly, no significantly increased risk was observed for patients with autoimmune disorders (Figure S3).

To further investigate the higher $\tau^{+}$prevalence in the group of patients with vascular, kidney and metabolic disorders, we analysed the risk ratios for autoantibodies in individual disease entities (Figure S4). Adjusted risk ratios for these entities were calculated by including all individual diseases with a statistically significant association (from Figure S4), as well as age and sex, into a multivariate log-binomial regression model (Figure 5B). This analysis revealed that cystitis (aRR $1.59,95 \% \mathrm{Cl} 1.14-2.16, \mathrm{P}=0.004)$, other urinary system disorders (including urinary tract infection, proteinuria, and others) (aRR 1.23, 95\% Cl 1.03-1.45, $\mathrm{P}=0.018$ ), chronic kidney disease (aRR 1.20, 95\% Cl 1.01-1.41, $\mathrm{P}=0.033$ ), arterial embolism and thrombosis (aRR $1.56,95 \% \mathrm{Cl} 1.02-2.25, \mathrm{P}=0.026$ ) and atherosclerosis (aRR $1.35,95 \% \mathrm{Cl} 1.09-1.66, \mathrm{P}=0.004)$, as well as female sex (aRR 1.24, 95\% Cl 1.11-1.40, $\mathrm{P}<0.001)$, and age (aRR 1.007, 95\%Cl 1.003$1.01, \mathrm{P}<0.001$ ) were independent predictors of $\tau^{+}$autoantibodies (Figure $5 \mathrm{~B}$ ). The association with kidney disease is consistent with the highest adjusted $\tau^{+}$risk ratio in the department of nephrology (Figure 3E). We thus conclude that vascular, kidney and urinary disease, older age and female sex are associated with tau autoimmunity. A sensitivity analysis with a higher cutoff for defining plasma samples as positives for anti-tau autoantibodies, $-\log _{10}\left(E_{50}\right) \geq 2.2$, revealed similarly increased risk ratios for the presence of anti-tau antibodies in samples from patients with vascular, kidney and urinary disorders, and also heart disease (Figure S5). 
medRxiv preprint doi: https://doi.org/10.1101/2021.11.24.21266833; this version posted November 26, 2021. The copyright holder for this preprint (which was not certified by peer review) is the author/funder, who has granted medRxiv a license to display the preprint in It is made available under a CC-BY-NC 4.0 International license .

\section{Anti-tau autoantibodies and laboratory parameters}

We then examined the association of tau autoimmunity with specific changes in clinical chemistry laboratory data as a surrogate marker of disease independent of clinical diagnosis based on ICD-10 codes. We used available clinical chemistry laboratory data obtained within \pm 180 days of the blood withdrawal of the patient (Table S3). We found that $\tau^{+}$patients had a significantly higher prevalence of parameters characteristic of chronic kidney disease such as abnormal creatinine, urea, potassium, and phosphate (Table S3). The risk ratios for $\tau^{+}$were highest for creatinine (aRR 1.32, 95\% Cl 1.15-1.52, $\mathrm{P}<0.001)$ and potassium (aRR 1.36, 95\% Cl 1.13-1.61, $\mathrm{P}=0.010$ ) levels above the upper normal limit (Figure 6A).

Using the estimated glomerular filtration rate (eGFR) levels as a surrogate for kidney function, we classified the samples as having chronic kidney disease, according to KDIGO guidelines [35], if at least 2 measures of eGFR were lower than $60 \mathrm{~mL} / \mathrm{min} / 1.73 \mathrm{~m}^{2}$ for at least 3 months (Figure 6B). Our results show that $\tau^{+}$plasma was associated with chronic kidney disease (CKD) (aRR 1.38, 95\% Cl 1.09-1.72, $\mathrm{P}=0.005$ ) (Figure 6B and 6C). In addition, $\mathrm{\tau}^{+}$patients had a higher eGFR difference between the measurements of eGFR over time (before the tau microELISA screen and the most recent available measurement after the screen) (Figure 6D), suggesting a decline in kidney function over time. 
medRxiv preprint doi: https://doi.org/10.1101/2021.11.24.21266833; this version posted November 26, 2021. The copyright holder for this preprint (which was not certified by peer review) is the author/funder, who has granted medRxiv a license to display the preprint in It is made available under a CC-BY-NC 4.0 International license.

\section{Discussion}

This cross-sectional study of more than 40'000 samples from hospital patients and healthy blood donors shows that natural MTBD-tau IgG autoantibodies are associated with specific systemic diseases. Female sex, older age and the diagnosis of vascular, kidney and urinary disorders increased the risk of patients having high titers of plasma natural anti-tau autoantibodies, an observation further supported by laboratory data. In a multivariate analysis, cystitis, other urinary system disorders (including urinary tract infection, proteinuria), chronic kidney disease, arterial embolism and thrombosis, atherosclerosis, female sex, and age were independent predictors of plasma natural tau autoimmunity.

The general prevalence of natural MTBD-tau IgG autoantibodies was about $5 \%$ in our unselected hospital cohort, which is much higher than the suggested prevalence of other neuronal autoantibodies, with a seroprevalence of $<2.5 \%[36,37]$. This surprising finding prompted us to examine the specificity of these antibodies to MTBD. Using several orthogonal methods, including different immunoassays, Western blot analysis and immunocytochemical stains, we confirmed that natural anti-tau autoantibodies from $\tau^{+}$samples are highly specific for tau. Additionally, we found that the humoral immune response was polyclonal in at least half of the investigated samples.

As tau aggregation is a hallmark of several neurodegenerative diseases, most studies have investigated the role of tau and anti-tau antibodies in the nervous system. However, microtubule-associated protein tau gene (MAPT) is not only highly expressed in the brain but also in kidneys and skeletal muscle [1] and has been described to have functions beyond the regulation of microtubule dynamics [42-45]. Furthermore, natural anti-tau autoimmune responses were found in patients with $A D$ and non-neurodegeneration controls $[21,38]$, and tau antibodies have also been recovered from pooled human immunoglobulins [39-41]. In view of these findings, it is not implausible to speculate that natural tau antibodies may be associated with systemic diseases.

Several findings suggest that tau autoimmunity is indeed associated with disease. First, we detected a higher prevalence of plasma anti-tau autoantibodies in samples from university hospital patients $(5 \%)$ than in healthy donor samples $(1.6 \%)(P<0.001)$. Using a multivariate log-binomial regression model with age and sex, we estimated that the risk ratio for $\tau^{+}$was 2.37 times higher for hospital patients than for healthy donors $(P<0.001)$. Moreover, vascular, kidney and urinary disorders were independent predictors of plasma anti-tau autoantibodies, 
medRxiv preprint doi: https://doi.org/10.1101/2021.11.24.21266833; this version posted November 26, 2021. The copyright holder for this preprint (which was not certified by peer review) is the author/funder, who has granted medRxiv a license to display the preprint in It is made available under a CC-BY-NC 4.0 International license .

as were older age and female sex. Imbalance of phosphate, calcium and parathormone levels are known to contribute to vascular calcification in chronic kidney disease patients (CKD) [46], which in turn increases the mortality and morbidity risk of CKD patients [47]. Moreover, CKD patients also have higher risk of atherosclerosis [48]. In this study, higher anti-tau titers were associated with CKD, atherosclerosis and arterial embolism and thrombosis as well as higher phosphate levels, which could suggest an association between tau autoimmunity and a specific high vascular risk CKD phenotype. Additionally, we show a decline in kidney function over time in patients with plasma anti-tau autoantibodies. These findings highlight a potential role for natural anti-tau autoantibodies as biomarkers and/or precipitants of disease. Plasma anti-tau autoantibodies could potentially be a secondary manifestation of disease and a marker of disease affecting tissues with high levels of tau expression during which intracellular tau released by cell death could trigger autoantibodies that bypass immune tolerance mechanisms. Moreover, plasma tau autoantibodies could also potentially be a primary mediator of disease initiation and trigger tissue damage. A link between infection and autoimmunity has been described with several studies suggesting that infections can trigger autoimmunity such as in rheumatic fever and Guillain-Barré syndrome [49]. Interestingly, in cystitis and other urinary system disorders (including unspecified urinary tract infection), was associated with the presence of plasma anti-tau autoantibodies. However, the causality of plasma anti-tau autoantibodies in vascular, kidney and urinary disorders cannot be extrapolated from our cross-sectional design. Further replication in longitudinal cohorts may shed more light into the causality chains.

Several recent studies have investigated and proposed the use of plasma measurements of total and phosphorylated tau as biomarkers for both the diagnosis and monitoring of $A D$ progression [7-15]. Although it is not known if the presence of anti-tau autoantibodies could change the plasma levels of tau, it is known that the administration of anti-tau antibodies can alter the levels of plasma tau $[50,51]$. An increasing number of tau immunotherapy strategies are entering clinical settings [52]. Clinical trials using passive [53-56] and active [57] tau immunotherapy did not report an association between tau immunotherapy and systemic disease. However, the antibodies used in these therapies target different tau epitopes, including phospho-epitopes or the $\mathrm{N}$-terminus of tau, and were early phase clinical trials with a restricted number of participants and follow-up time. Our study describes associations of MTBD-tau autoimmunity and disease based on diagnostic codes controlled for potential 
medRxiv preprint doi: https://doi.org/10.1101/2021.11.24.21266833; this version posted November 26,2021 . The copyright holder for this preprint (which was not certified by peer review) is the author/funder, who has granted medRxiv a license to display the preprint in It is made available under a CC-BY-NC 4.0 International license .

confounders (age and sex) that are further supported by laboratory data. These findings call for careful monitoring of potential adverse effects of tau immunotherapy in clinical settings. Our large-scale assessment of plasma tau autoimmunity may suffer from potential limitations. The highest number of samples analysed in our study were collected from a university hospital cohort, which may be biased in favor of complex diseases. In order to circumvent this issue, we collected samples from a blood donor cohort that represents a healthy population. However, this strategy may reduce the prevalence of common diseases encountered in community practices and not in university hospital centers. Another limitation is that a direct comparison of the prevalence of plasma anti-tau antibodies in these two cohorts is impaired by the different materials, collection and handling methods involved in the collection of these samples at two different sites. Additionally, our study is limited to two sites in a single region with approximately $1^{\prime} 500^{\prime} 000$ inhabitants whose ethnic composition was not studied in detail. Other limitations of our study are the restriction of the analysis to specific disease groups and the lack of a longitudinal disease cohort that could examine a time course and elucidate the origin and causal role of these autoantibodies. A further limitation is that we focused on detecting MTBD-tau IgG autoantibodies, and thus did not include other full-length tau or post-translationally modified tau epitopes or other antibody isotypes.

In conclusion, we studied a large university hospital and a healthy blood donor cohort and identified a previously unknown relatively high prevalence of plasma anti-tau autoantibodies, as well as an association between plasma anti-tau autoantibodies and disease outside the central nervous system. Vascular, kidney and urinary disorders, and female sex and older age were independent predictors of plasma tau autoimmunity. These associations were supported by laboratory data and a sensitivity analysis. Our findings reveal new potential roles for natural anti-tau autoantibodies in diseases outside the central nervous system and call for attentive clinical monitoring of such diseases in the study of therapeutic anti-tau antibodies. 
medRxiv preprint doi: https://doi.org/10.1101/2021.11.24.21266833; this version posted November 26,2021 . The copyright holder for this preprint (which was not certified by peer review) is the author/funder, who has granted medRxiv a license to display the preprint in It is made available under a CC-BY-NC 4.0 International license .

\section{Methods}

Study population, sample collection and biobanking

Collection of samples and clinical data were conducted according to study protocols approved by the Cantonal Ethics Committee of the Canton of Zurich, Switzerland (KEK-ZH Nr. 20150561, BASEC-Nr. 2018-01042, and BASEC-Nr. 2020-01731). From December 2017 until February 2020, residual heparin plasma samples were obtained from the Department of Clinical Chemistry, University Hospital of Zurich, Switzerland. In addition, we obtained from March to July 2020 EDTA plasma samples from the regional Blood Donation Center Zurich, from individuals aged $\geq 18$ years.

Samples were biobanked in 384-well plates and tested on an automated indirect microELISA high-throughput platform for IgG antibodies targeting the microtubule-binding-domain of tau (MTBD-tau, tauK18) (for details see $[32,58]$ and below). Demographic and clinical data for the University Hospital cohort was obtained from the hospital registry with follow-up until March 2020. Clinical data for the healthy blood donor cohort was not available for this study. For the $A D$ targeted screen, the cohort of $A D$ patients was selected from the University Hospital biobank based on international classification of disease version 10 (ICD-10) codes (G30 and F00) and the control cohort was selected based on exclusion of all ICD-10 codes for neurological diseases.

\section{Automated microELISA screen}

High-binding 1536-well plates (Perkin Elmer, SpectraPlate $1536 \mathrm{HB}$ ) were coated with $1 \mathrm{ug} / \mathrm{mL}$ of in-house produced MTBD-tau (see protocol below) at $37{ }^{\circ} \mathrm{C}$ for $60 \mathrm{~min}$. Plates were then washed 3x with phosphate-buffered saline 0.1\% Tween ${ }^{\circledR} 20$ (PBST) using a Biotek El406 washer dispenser. Plates were blocked for 90 min with $5 \%$ milk (Migros) in PBST. $3 \mu \mathrm{L}$ of heparin plasma was diluted in $57 \mu \mathrm{L}$ of $1 \%$ milk in PBST and dispensed into the tau-coated plates in different volumes (1200-7.5 nL) using acoustic dispensing with an ECHO 555 Liquid Handler (Labcyte/Beckman Coulter). Pooled human, IgG-depleted serum (MyBioSource) was used as negative control and anti-tau RD4 (4-repeat isoform) mouse monoclonal antibody clone 1E1/A6 (05-804 Merck Millipore) as positive control. 1\% milk in PBST was used to fill up wells to a final volume of $3 \mu \mathrm{L}$ using a Certus Flex (Fritz Gyger AG). Eight dilution points (range: 1:50 to $\left.1: 6^{\prime} 000\right)$ were generated for each plasma sample. Samples were incubated for 120 min at room temperature (RT) after which plates were washed $5 \mathrm{x}$ with PBST. $3 \mu \mathrm{L}$ of 
medRxiv preprint doi: https://doi.org/10.1101/2021.11.24.21266833; this version posted November 26,2021 . The copyright holder for this preprint (which was not certified by peer review) is the author/funder, who has granted medRxiv a license to display the preprint in It is made available under a CC-BY-NC 4.0 International license.

secondary antibody (peroxidase AffiniPure goat Anti-Mouse IgG $\mathrm{H}+\mathrm{L}$ (Jackson ImmunoResearch 115-035-003) 1:2000 diluted in 1\% milk PBST for the monoclonal antibody controls and peroxidase AffiniPure goat Anti-Human IgG Fc-gamma specific (Jackson ImmunoResearch 109-035-098) 1:4000 diluted in 1\% milk PBST for the human plasma samples) were dispensed into the plates using a Biotek MultifloFX dispenser. Secondary antibodies were incubated for $60 \mathrm{~min}$ at RT after which plates were washed $3 x$ with PBST. 3 $\mu \mathrm{L}$ of TMB Chromogen Solution for ELISA (Invitrogen) was added to the plates as colorimetric HRP substrate and incubated for 3 min at RT. Finally, $3 \mu \mathrm{L}$ of $0.5 \mathrm{M} \mathrm{H}_{2} \mathrm{SO}_{4}$ was added to each reaction and plates were analyzed at $\lambda=450 \mathrm{~nm}$ in a plate reader (Perkin Elmer, Envision). Negative logarithm half-maximal response $\left(-\log _{10}\left(E C_{50}\right)\right)$ values were determined by fitting the eight dilutions for each plasma sample to an equation for a simple binding equilibrium between antibody and the bound tau with baseline and maximal signal plateau being fixed by the negative and positive controls for each plate [58]. Samples with a fitting error $>20 \%$ of the $-\log _{10}\left(E_{50}\right)$ were classified as non-fittable and were not included in the analysis. We used $-\log _{10}\left(E C_{50}\right)$ as a surrogate of antibody titers and classified positives/hits as samples with a high $-\log _{10}\left(E C_{50}\right)$, using a cut-off of $-\log _{10}\left(E C_{50}\right) \geq 1.8$ for the primary screen. For the sensitivity analysis, a cut-off of $-\log _{10}\left(E C_{50}\right) \geq 2.2$ was used.

The replicability of the assay was evaluated by testing 308 samples in duplicates using the same microELISA high-throughput platform, running the replicates on the same day, but using different 1536-well assay (destination) plates, different plate coordinates for each replicate, and calculating the $-\log _{10}\left(E C_{50}\right)$ of each replicate independently.

\section{Production and purification of recombinant Tau}

The gene encoding the MTBD-tau protein was cloned into the T7 expression vector, PRSET-A (Invitrogen). The plasmid encoding the full-length tau protein (tau/pET29b, Addgene \#16316) was a gift from Peter Klein [59]. For protein expression the respective vector was transformed into E.coli BL21-DE3 cells. Cells were grown in Luria Broth (LB) medium at $37^{\circ} \mathrm{C}$ until an $\mathrm{OD}_{600}$ of 0.8 was reached, before they were induced with isopropyl- $\beta$-D-thiogalactoside (IPTG) at a final concentration of $1 \mathrm{mM}$. After growing the cells for $6 \mathrm{~h}$ at $37^{\circ} \mathrm{C}$, cultures were harvested by centrifugation. Pellets were suspended in $20 \mathrm{mM}$ piperazine-N,N-bis(2-ethanesulfonic) acid (PIPES), $\mathrm{pH}$ 6.5, $1 \mathrm{mM}$ ethylenediaminetetraacetic acid (EDTA) and $50 \mathrm{mM}$ 2mercaptoethanol buffer and sonicated for $30 \mathrm{~min}$. $\mathrm{NaCl}$ to a final concentration of $500 \mathrm{mM}$ 
medRxiv preprint doi: https://doi.org/10.1101/2021.11.24.21266833; this version posted November 26,2021 . The copyright holder for this preprint (which was not certified by peer review) is the author/funder, who has granted medRxiv a license to display the preprint in It is made available under a CC-BY-NC 4.0 International license .

was added and samples were boiled for $20 \mathrm{~min}$. Debris were removed by centrifugation and soluble tau was precipitated at a final ammonium sulfate saturation of $55 \%$. Samples were again centrifuged and the supernatant was resuspended in 20 mM HEPES, pH 7.0, 2 mM DTT. The supernatant was passed through a $0.45 \mu \mathrm{m}$ Acrodisc filter and loaded onto a Sepharose SP Fast Flow resin for cation-exchange chromatography. MTBD-tau was eluted from the column via a linear salt gradient from 0 to $1 \mathrm{M} \mathrm{NaCl}$ in 20 mM HEPES, pH 7.0, 2 mM DTT. After buffer exchange to phosphate-buffered saline (PBS), the pooled samples were further purified by size-exclusion chromatography using a HiLoad 26/60 Superdex75 (GE Healthcare). Fractions containing pure tau were pooled, concentrated in an Amicon Ultra-15 centrifugal filter unit (10-kDa MWCO) and stored until further use at $-80^{\circ} \mathrm{C}$.

\section{Purification of anti-tau autoantibodies from patient samples}

Heparin plasma (between $3 \mathrm{~mL}$ and $20 \mathrm{~mL}$ from 4 patients) was diluted 1:1 in PBS and loaded on a column containing $3 \mathrm{~mL}$ of epoxy-MTBD-tau (prepared with a previous overnight incubation of tau and epoxy resin in a binding buffer of $0.1 \mathrm{M} \mathrm{NaH}_{2} \mathrm{PO}_{4}-\mathrm{NaOH}, 1 \mathrm{M} \mathrm{NaCl}, \mathrm{pH}$ 9.2) by repetitive loading of the sample overnight at $4{ }^{\circ} \mathrm{C}$. The column was washed with 40 $\mathrm{mL}$ of PBS, and tau autoantibodies were eluted twice with $2 \mathrm{~mL} 0.1 \mathrm{M}$ glycine- $\mathrm{HCl}, \mathrm{pH} 2.5$, and immediately neutralized to $\mathrm{pH} 7.0$ with $1 \mathrm{M}$ Tris. Fractions containing the eluted antibodies were pooled and concentrated using Amicon Ultra- $0.5 \mathrm{~mL}$ centrifugal filters (50 kDa MWCO).

\section{Competition ELISA assays}

For the competition ELISAs, high-binding 384-well plates (Perkin Elmer, SpectraPlate $384 \mathrm{HB}$ ) were coated with $20 \mu \mathrm{L}$ of $0.5 \mu \mathrm{g} / \mathrm{mL}$ of MTBD-tau at $4{ }^{\circ} \mathrm{C}$ overnight. Afterwards, plates were washed 3x with PBST with a Biotek El406 washer dispenser and blocked with $95 \mu \mathrm{L} 5 \%$ SureBlock ${ }^{\mathrm{TM}}$ (Lubio) in PBST for 120 min. Patient purified tau autoantibodies were diluted 1:50 in $1 \%$ SureBlock ${ }^{\mathrm{TM}}$ in PBST. Albumin (Sigma), recombinant MTBD-tau, a pool of eight synthetic MTBD-tau peptides with 25 amino acids length and 10 amino acids of overlap and an unrelated 25 amino acid length synthetic TREM2 peptide (GenScript) were used as competing antigens. Competing antigens were serially diluted from $10 \mu \mathrm{M}$ to $2.44 \mathrm{nM}$ in six serial 2-fold dilutions in $1 \%$ SureBlock $^{\text {TM }}$ in PBST. Purified autoantibodies and competing antigens were incubated at RT for 45 min, transferred to the MTBD-tau coated microtiter plate, incubated 
medRxiv preprint doi: https://doi.org/10.1101/2021.11.24.21266833; this version posted November 26, 2021. The copyright holder for this preprint (which was not certified by peer review) is the author/funder, who has granted medRxiv a license to display the preprint in It is made available under a CC-BY-NC 4.0 International license .

for 60 min at RT and then 3x washed with PBST using a Biotek El406 washer dispenser. $20 \mu \mathrm{L}$ of secondary antibody peroxidase (AffiniPure goat Anti-Human IgG Fc-gamma specific; Jackson ImmunoResearch 109-035-098) were incubated for $60 \mathrm{~min}$ at RT and plates were washed $3 x$ with PBST. $20 \mu \mathrm{L}$ of TMB Chromogen Solution for ELISA (Invitrogen) as colorimetric HRP substrate was added to the plates as colorimetric HRP substrate and incubated for $5 \mathrm{~min}$ at RT. Then $5 \mu \mathrm{L}$ of $0.5 \mathrm{M} \mathrm{H}_{2} \mathrm{SO}_{4}$ was added to the reaction and plates were analysed at an optical density of $\lambda=450 \mathrm{~nm}$ in a plate reader (SpectraMax ${ }^{\circledR}$ Paradigm $^{\circledR}$, Molecular Devices).

\section{Indirect ELISA assays}

To test for possible polyreactivity, purified anti-tau antibodies were tested by indirect ELISA against several antigens [60, 61]. High-binding 384-well plates (Perkin Elmer, SpectraPlate 384 HB) were coated with $20 \mu \mathrm{L}$ of $1 \mu \mathrm{g} / \mathrm{mL}$ of MTBD-tau, $10 \mu \mathrm{g} / \mathrm{mL}$ of DNA from calf-thymus (Sigma), $10 \mu \mathrm{g} / \mathrm{mL}$ of lipopolysaccharides, $5 \mu \mathrm{g} / \mathrm{mL}$ of insulin, $10 \mu \mathrm{g} / \mathrm{mL}$ of albumin, $2 \mu \mathrm{g} / \mathrm{mL}$ of cardiolipin or left uncoated at $4{ }^{\circ} \mathrm{C}$ overnight. Plates were washed $3 x$ with phosphatebuffered saline $0.1 \%$ Tween ${ }^{\circledR} 20$ (PBST) with a Biotek El406 washer dispenser and then blocked with $95 \mu \mathrm{L}$ 5\% SureBlock ${ }^{\mathrm{TM}}$ (Lubio) in PBST for $120 \mathrm{~min}$. Patient purified tau autoantibodies and patient plasma were diluted 1:30 and 1:50, respectively. The following controls were used: IgG-depleted plasma (BioSource) 1:50 diluted as negative control; anti-DNP (Sigma) at a final concentration of $6 \mu \mathrm{g} / \mathrm{mL}$, anti-RD4 (Millipore) at $6 \mu \mathrm{g} / \mathrm{mL}$, and pooled plasma from 20 patients diluted 1:25 with 1\% SureBlock ${ }^{\mathrm{TM}}$ in PBST as positive controls. Samples were serially diluted 12 times 1:1 with 1\% SureBlock ${ }^{\mathrm{TM}}$ in PBST in the referred plates. Samples were incubated for $120 \mathrm{~min}$ at RT. Plates were then washed 3x with PBST using a Biotek El406 washer dispenser. $20 \mu \mathrm{L}$ of secondary antibodies peroxidase AffiniPure goat Anti-Human IgG Fc-gamma specific (Jackson ImmunoResearch 109-035-098), peroxidase AffiniPure goat AntiMouse IgG and peroxidase AffiniPure mouse Anti-Rabbit IgG were incubated for 60 min at RT. Plates were then washed $3 x$ with PBST. $20 \mu \mathrm{L}$ of TMB Chromogen Solution for ELISA (Invitrogen) was added as colorimetric HRP substrate to the plates and incubated for 5 min at RT. Finally, $5 \mu \mathrm{L}$ of $0.5 \mathrm{M} \mathrm{H}_{2} \mathrm{SO}_{4}$ was added to the reaction and plates were analysed at an optical density of $\lambda=450 \mathrm{~nm}$ in a plate reader (SpectraMax ${ }^{\circledR}$ Paradigm $^{\circledR}$, Molecular Devices). For immunoglobulin light chain typing, the following modifications and secondary antibodies were used: peroxidase AffiniPure goat Anti-Human IgG Fc-gamma specific (Jackson ImmunoResearch 109-035-098), Goat anti-human Kappa-HRP [32], or goat anti-human 
medRxiv preprint doi: https://doi.org/10.1101/2021.11.24.21266833; this version posted November 26, 2021. The copyright holder for this preprint (which was not certified by peer review) is the author/funder, who has granted medRxiv a license to display the preprint in It is made available under a CC-BY-NC 4.0 International license .

Lambda-HRP [32] 1:4000 diluted in 1\% SureBlock ${ }^{\mathrm{TM}}$ in PBST and incubated for 60 min at RT. For data analysis, samples were considered reactive when $\mathrm{OD} 450_{\mathrm{nm}}$ was higher than the average of all negatives $O D 450_{n m}+2 x$ the standard deviation of OD450 $n$ of the negatives. For immunoglobulin heavy chain subtyping, the following secondary antibodies were used: rabbit anti-human IgG1 (Thermo Fisher SA5-10202), IgG2 (Thermo Fisher SA5-10203), IgG3 (Thermo Fisher SA5-10204), IgG4 (Thermo Fisher SA5-10205), and AffiniPure Goat Anti-Rabbit IgG-HRP (Jackson ImmunoResearch).

For epitope mapping experiments, a similar approach was used in which 384-well plates (Perkin Elmer, SpectraPlate $384 \mathrm{HB}$ ) were coated with $20 \mu \mathrm{L}$ of $1 \mu \mathrm{g} / \mathrm{mL}$ of each MTBD-tau peptide. A total of 8 MTBD-tau peptides with 25 amino acids length and 10 amino acids of overlap with the previous peptide and covering the sequence of MTBD-tau were obtained from GenScript.

\section{Western blot and immunocytochemical experiments}

For Western Blot assays, SH-SY5Y wild-type cells (Sigma) and SH-SY5Y cells overexpressing tau (P301LS320F) were lysed using 0.1\% TritonX (Sigma) in PBS. Protein content of the soluble fraction was measured using a bicinchoninic protein assay (Pierce BCA Protein Assay Kit, ThermoFisher) and $80 \mu \mathrm{g}$ of cell lysates were loaded onto NuPAGE $12 \%$ Bis-Tris gels (ThermoFisher). SDS-PAGE gels were run at $180 \mathrm{~V}$ in MES buffer for $45 \mathrm{~min}$ and then transferred onto nitrocellulose membranes with a dry transfer system (iBlot 2 Gel Transfer Device, ThermoFisher). Membranes were blocked with 5\% SureBlock (Lubio Science) in PBST for $30 \mathrm{~min}$ at room temperature and then incubated with a 1:100 dilution of purified tau autoantibodies in $1 \%$ SureBlock in PBST overnight at $4{ }^{\circ} \mathrm{C}$. Anti-tau RD4 (4-repeat isoform) mouse monoclonal antibody clone 1E1/A6 (05-804 Merck Millipore) diluted 1:4000 with 1\% SureBlock in PBST was used as a positive control. Membranes were washed $3 x$ for 5 min with PBST and then incubated with the following secondary antibodies for $60 \mathrm{~min}$ at room temperature: peroxidase AffiniPure goat Anti-Mouse IgG H+L (Jackson ImmunoResearch 115035-003) and peroxidase AffiniPure goat Anti-Human IgG Fc-gamma specific (Jackson ImmunoResearch 109-035-098) 1:10'000 diluted with 1\% SureBlock in PBST. Anti-Actin antibody (Merck) 1:10'000 diluted with 1\% SureBlock in PBST was used as a loading control. Membranes were washed 4x 5min with PBST, developed using Immobilon Crescendo HRP Substrate and imaged using Fusion SOLO S imaging system (Vilber). 
medRxiv preprint doi: https://doi.org/10.1101/2021.11.24.21266833; this version posted November 26, 2021. The copyright holder for this preprint (which was not certified by peer review) is the author/funder, who has granted medRxiv a license to display the preprint in It is made available under a CC-BY-NC 4.0 International license .

SH-SY5Y cells were transfected with pRK5-EGFP-0N4Rtau plasmid (Addgene \# 46904, a kind gift of Dr Karen Ashe[62]) using Lipofectamine ${ }^{\circledR} 2000$ according to manufacturer's protocol. After $48 \mathrm{~h}$ cells were fixed with $4 \%$ paraformaldehyde, cells were permeabilized with $0.5 \%$ bovine serum albumin (BSA), $0-1 \%$ Triton $^{\mathrm{TM} X} \mathrm{X}-100$ in PBS and blocked with $0.5 \%$ bovine serum albumin in PBS. For immunocytochemical assays, 1:25 purified tau autoantibodies diluted with $0.5 \%$ BSA in PBS were incubated with the cells for 60 min. Tau mouse monoclonal antibody HT7 (MN1000 Thermo Fisher Scientific) was used as a positive control. Cells were washed $3 x$ with $0.5 \%$ BSA in PBS and incubated with either antimouse-Alexa555 1:500 or goat anti-human biotin-conjugated 1:200 for 30 min. Samples were $3 x$ washed with $0.5 \%$ BSA in PBS. For human antibody stains, samples were further incubated with streptavidin-Alexa594 1:200 for 30 min. DAPI (4',6-diamidino-2-phenylindole) 1:10'000 was used for DNA staining. Cells were mounted on glass slides with Fluorescence Mounting Medium (Thermo Fisher Scientific) and imaged with using a Leica TCS SP5 confocal laser scanning microscope.

\section{Statistical analysis}

Demographic and clinical characteristics were obtained from the hospital registry. The ICD10 (International Classification of Disease and Related Health Problems, $10^{\text {th }}$ revision) codes in this study are mainly used for health-care billing purpose and have been re-used by us for quantitative data analysis. Age and laboratory parameters are presented as medians (with interquartile ranges). Categorized age and sample contributions of clinical departments are presented as percentages. Comparisons of age and laboratory parameters were performed using non-parametric Mann-Whitney $U$ test. Comparisons of prevalence of positive and negative samples according to sex and department of origin were performed using a proportion test. We used log-binomial regression models $[33,63]$ to characterize the association between the presence of plasma tau autoantibodies and demographic characteristics or medical conditions. Risk ratios and $95 \%$ confidence intervals were calculated by defining presence or absence of tau autoantibodies as the outcome and presence or absence of disease as the exposure. Diseases as predictors of plasma tau autoantibodies presence were analysed in a multivariate analysis that included age and sex. The first analysis used main groups of diseases, followed by an individual disease entities analysis. Individual disease entities with a $\mathrm{P}$ value $<0.05$ corrected for multiple comparisons were included in a multivariate log-binomial regression analyses. A sensitivity analysis was 
medRxiv preprint doi: https://doi.org/10.1101/2021.11.24.21266833; this version posted November 26, 2021. The copyright holder for this preprint (which was not certified by peer review) is the author/funder, who has granted medRxiv a license to display the preprint in It is made available under a CC-BY-NC 4.0 International license.

performed for the 14 main systemic disorders using a higher cut-off $-\log _{10}\left(E_{50}\right) \geq 2.2$ for the classification of positives. Statistical significance was defined by 2 -tailed $P$ value $\leq 0.05$. $P$ value was corrected for multiple comparisons using Bonferroni's method when applicable and as described in each figure/table. Statistical analyses were performed using RStudio version 1.2.1335 software. This report is in accordance with the STROBE guidelines.

\section{References}

1. Uhlén, M., et al., Proteomics. Tissue-based map of the human proteome. Science, 2015. 347(6220): p. 1260419.

2. Gu, Y., F. Oyama, and Y. Ihara, Tau is widely expressed in rat tissues. J Neurochem, 1996. 67(3): p. 1235-44.

3. Kosik, K.S., C.L. Joachim, and D.J. Selkoe, Microtubule-associated protein tau (tau) is a major antigenic component of paired helical filaments in Alzheimer disease. Proc Natl Acad Sci U S A, 1986. 83(11): p. 4044-8.

4. Joachim, C.L., et al., Tau antisera recognize neurofibrillary tangles in a range of neurodegenerative disorders. Ann Neurol, 1987. 22(4): p. 514-20.

5. Hanseeuw, B.J., et al., Association of Amyloid and Tau With Cognition in Preclinical Alzheimer Disease: A Longitudinal Study. JAMA Neurol, 2019.

6. Hanseeuw, B.J., et al., Fluorodeoxyglucose metabolism associated with tau-amyloid interaction predicts memory decline. Ann Neurol, 2017. 81(4): p. 583-596.

7. Mattsson, N., et al., Plasma tau in Alzheimer disease. Neurology, 2016. 87(17): p. 1827-1835.

8. Palmqvist, S., et al., Discriminative Accuracy of Plasma Phospho-tau217 for Alzheimer Disease vs Other Neurodegenerative Disorders. JAMA, 2020.

9. Janelidze, S., et al., Plasma P-tau181 in Alzheimer's disease: relationship to other biomarkers, differential diagnosis, neuropathology and longitudinal progression to Alzheimer's dementia. Nat Med, 2020. 26(3): p. 379-386.

10. Moscoso, A., et al., Longitudinal Associations of Blood Phosphorylated Tau181 and Neurofilament Light Chain With Neurodegeneration in Alzheimer Disease. JAMA Neurol, 2021. 78(4): p. 396-406.

11. Barthélemy, N.R., et al., A soluble phosphorylated tau signature links tau, amyloid and the evolution of stages of dominantly inherited Alzheimer's disease. Nat Med, 2020. 26(3): p. 398-407.

12. Karikari, T.K., et al., Blood phosphorylated tau 181 as a biomarker for Alzheimer's disease: a diagnostic performance and prediction modelling study using data from four prospective cohorts. Lancet Neurol, 2020. 19(5): p. 422-433.

13. Park, J.C., et al., Plasma tau/amyloid-61-42 ratio predicts brain tau deposition and neurodegeneration in Alzheimer's disease. Brain, 2019. 142(3): p. 771-786.

14. Pase, M.P., et al., Assessment of Plasma Total Tau Level as a Predictive Biomarker for Dementia and Related Endophenotypes. JAMA Neurol, 2019. 76(5): p. 598-606.

15. Mielke, M.M., et al., Association of Plasma Total Tau Level With Cognitive Decline and Risk of Mild Cognitive Impairment or Dementia in the Mayo Clinic Study on Aging. JAMA Neurol, 2017. 74(9): p. 1073-1080. 
medRxiv preprint doi: https://doi.org/10.1101/2021.11.24.21266833; this version posted November 26, 2021. The copyright holder for this preprint (which was not certified by peer review) is the author/funder, who has granted medRxiv a license to display the preprint in

perpetuity.
It is made available under a CC-BY-NC 4.0 International license .

16. Asuni, A.A., et al., Immunotherapy targeting pathological tau conformers in a tangle mouse model reduces brain pathology with associated functional improvements. J Neurosci, 2007. 27(34): p. 9115-29.

17. Boutajangout, A., et al., Passive immunization targeting pathological phospho-tau protein in a mouse model reduces functional decline and clears tau aggregates from the brain. J Neurochem, 2011. 118(4): p. 658-67.

18. Congdon, E.E. and E.M. Sigurdsson, Tau-targeting therapies for Alzheimer disease. Nat Rev Neurol, 2018. 14(7): p. 399-415.

19. Venkatesan, A., et al., Acute encephalitis in immunocompetent adults. Lancet, 2019. 393(10172): p. 702-716.

20. Wootla, B., et al., Naturally Occurring Monoclonal Antibodies and Their Therapeutic Potential for Neurologic Diseases. JAMA Neurol, 2015. 72(11): p. 1346-53.

21. Pascual, G., et al., Immunological memory to hyperphosphorylated tau in asymptomatic individuals. Acta Neuropathol, 2017. 133(5): p. 767-783.

22. Zhang, H., et al., Structural Basis for Recognition of a Unique Epitope by a Human Antitau Antibody. Structure, 2018. 26(12): p. 1626-1634.e4.

23. Apetri, A., et al., A common antigenic motif recognized by naturally occurring human V. Acta Neuropathol Commun, 2018. 6(1): p. 43.

24. Sandusky-Beltran, L.A. and E.M. Sigurdsson, Tau immunotherapies: Lessons learned, current status and future considerations. Neuropharmacology, 2020. 175: p. 108104.

25. Marciniak, E., et al., Tau deletion promotes brain insulin resistance. J Exp Med, 2017. 214(8): p. 2257-2269.

26. Rothstein, T.L., Natural Antibodies as Rheostats for Susceptibility to Chronic Diseases in the Aged. Front Immunol, 2016. 7: p. 127.

27. Lutz, H.U., C.J. Binder, and S. Kaveri, Naturally occurring auto-antibodies in homeostasis and disease. Trends Immunol, 2009. 30(1): p. 43-51.

28. Rosenmann, H., et al., Detection of circulating antibodies against tau protein in its unphosphorylated and in its neurofibrillary tangles-related phosphorylated state in Alzheimer's disease and healthy subjects. Neurosci Lett, 2006. 410(2): p. 90-3.

29. Bartos, A., L. Fialová, and J. Švarcová, Lower Serum Antibodies Against Tau Protein and Heavy Neurofilament in Alzheimer's Disease. J Alzheimers Dis, 2018. 64(3): p. 751-760.

30. Kronimus, Y., et al., Naturally Occurring Autoantibodies against Tau Protein Are Reduced in Parkinson's Disease Dementia. PLoS One, 2016. 11(11): p. e0164953.

31. Wu, J. and L. Li, Autoantibodies in Alzheimer's disease: potential biomarkers, pathogenic roles, and therapeutic implications. J Biomed Res, 2016. 30(5): p. 361-372.

32. Senatore, A., et al., Protective anti-prion antibodies in human immunoglobulin repertoires. EMBO Mol Med, 2020. 12(9): p. e12739.

33. Diaz-Quijano, F.A., A simple method for estimating relative risk using logistic regression. BMC Med Res Methodol, 2012. 12: p. 14.

34. Donoghoe, M.W. and I.C. Marschner, logbin: An R Package for Relative Risk Regression Using the Log-Binomial Model. Journal of Statistical Software, 2018. 86(9): p. 21.

35. Levin, A., et al., Kidney disease: Improving global outcomes (KDIGO) CKD work group. KDIGO 2012 clinical practice guideline for the evaluation and management of chronic kidney disease. Kidney International Supplements, 2013. 3(1): p. 149.

36. Dahm, L., et al., Seroprevalence of autoantibodies against brain antigens in health and disease. Ann Neurol, 2014. 76(1): p. 82-94. 
medRxiv preprint doi: https://doi.org/10.1101/2021.11.24.21266833; this version posted November 26,2021 . The copyright holder for this preprint (which was not certified by peer review) is the author/funder, who has granted medRxiv a license to display the preprint in It is made available under a CC-BY-NC 4.0 International license .

37. Lang, K. and H. Prüss, Frequencies of neuronal autoantibodies in healthy controls: Estimation of disease specificity. Neurol Neuroimmunol Neuroinflamm, 2017. 4(5): p. e386.

38. Lindestam Arlehamn, C.S., et al., Widespread Tau-Specific CD4 T Cell Reactivity in the General Population. J Immunol, 2019. 203(1): p. 84-92.

39. Hromadkova, L., et al., Identification and characterization of natural antibodies against tau protein in an intravenous immunoglobulin product. J Neuroimmunol, 2015. 289: p. 121-9.

40. Smith, L.M., M.P. Coffey, and D.A. Loeffler, Specific binding of intravenous immunoglobulin products to tau peptide fragments. Int Immunopharmacol, 2014. 21(2): p. 279-82.

41. Krestova, M., et al., Characterization of isolated tau-reactive antibodies from the IVIG product, plasma of patients with Alzheimer's disease and cognitively normal individuals. J Neuroimmunol, 2017. 313: p. 16-24.

42. Sotiropoulos, I., et al., Atypical, non-standard functions of the microtubule associated Tau protein. Acta Neuropathol Commun, 2017. 5(1): p. 91.

43. Rinschen, M.M., et al., A Multi-layered Quantitative In Vivo Expression Atlas of the Podocyte Unravels Kidney Disease Candidate Genes. Cell Rep, 2018. 23(8): p. 24952508.

44. Reiser, J. and S. Sever, Podocyte biology and pathogenesis of kidney disease. Annu Rev Med, 2013. 64: p. 357-66.

45. Ho, K.H., et al., Glucose Regulates Microtubule Disassembly and the Dose of Insulin Secretion Via Tau Phosphorylation. Diabetes, 2020.

46. Goodman, W.G., et al., Coronary-artery calcification in young adults with end-stage renal disease who are undergoing dialysis. N Engl J Med, 2000. 342(20): p. 1478-83.

47. Sigrist, M.K., et al., Progressive vascular calcification over 2 years is associated with arterial stiffening and increased mortality in patients with stages 4 and 5 chronic kidney disease. Clin J Am Soc Nephrol, 2007. 2(6): p. 1241-8.

48. Valdivielso, J.M., et al., Atherosclerosis in Chronic Kidney Disease: More, Less, or Just Different? Arterioscler Thromb Vasc Biol, 2019. 39(10): p. 1938-1966.

49. $\quad$ Bach, J.F., Infections and autoimmune diseases. J Autoimmun, 2005. 25 Suppl: p. 7480.

50. Yanamandra, K., et al., Anti-tau antibody administration increases plasma tau in transgenic mice and patients with tauopathy. Sci Transl Med, 2017. 9(386).

51. Ayalon, G., et al., Antibody semorinemab reduces tau pathology in a transgenic mouse model and engages tau in patients with Alzheimer's disease. Sci Transl Med, 2021. 13(593).

52. Jadhav, S., et al., $A$ walk through tau therapeutic strategies. Acta Neuropathol Commun, 2019. 7(1): p. 22.

53. Boxer, A.L., et al., Safety of the tau-directed monoclonal antibody BllB092 in progressive supranuclear palsy: a randomised, placebo-controlled, multiple ascending dose phase $1 b$ trial. Lancet Neurol, 2019. 18(6): p. 549-558.

54. Vaswani, P.A. and A.L. Olsen, Immunotherapy in progressive supranuclear palsy. Curr Opin Neurol, 2020. 33(4): p. 527-533.

55. Dam, T., et al., Safety and efficacy of anti-tau monoclonal antibody gosuranemab in progressive supranuclear palsy: a phase 2, randomized, placebo-controlled trial. Nat Med, 2021. 27(8): p. 1451-1457. 
medRxiv preprint doi: https://doi.org/10.1101/2021.11.24.21266833; this version posted November 26,2021 . The copyright holder for this preprint (which was not certified by peer review) is the author/funder, who has granted medRxiv a license to display the preprint in It is made available under a CC-BY-NC 4.0 International license .

56. Höglinger, G.U., et al., Safety and efficacy of tilavonemab in progressive supranuclear palsy: a phase 2, randomised, placebo-controlled trial. Lancet Neurol, 2021. 20(3): p. 182-192.

57. Novak, P., et al., Safety and immunogenicity of the tau vaccine AADvac1 in patients with Alzheimer's disease: a randomised, double-blind, placebo-controlled, phase 1 trial. Lancet Neurol, 2017. 16(2): p. 123-134.

58. Emmenegger, M., et al., Early peak and rapid decline of SARS-CoV-2 seroprevalence in a Swiss metropolitan region. medRxiv, 2020.

59. Hedgepeth, C.M., et al., Activation of the Wnt signaling pathway: a molecular mechanism for lithium action. Dev Biol, 1997. 185(1): p. 82-91.

60. Bunker, J.J., et al., Natural polyreactive IgA antibodies coat the intestinal microbiota. Science, 2017. 358(6361).

61. Mouquet, $\mathrm{H}_{\text {., }}$ et al., Polyreactivity increases the apparent affinity of anti-HIV antibodies by heteroligation. Nature, 2010. 467(7315): p. 591-5.

62. Hoover, B.R., et al., Tau mislocalization to dendritic spines mediates synaptic dysfunction independently of neurodegeneration. Neuron, 2010. 68(6): p. 1067-81.

63. McNutt, L.A., et al., Estimating the relative risk in cohort studies and clinical trials of common outcomes. Am J Epidemiol, 2003. 157(10): p. 940-3.

\section{Acknowledgments}

The authors wish to thank the hospital patients and blood donors for their generous altruistic contributions to this study. Imaging was performed with equipment maintained by the Center for Microscopy and Image Analysis, University of Zurich. We thank Dr. Marco Losa for the generous provision of secondary antibodies for light chain typing and Magdalena Bialkowska, Lisa Caflisch, Berre Doğançay, Julie Domange, Jingjing Guo, Marigona Imeri, Lorène Mottier, Rea Müller, Antonella Rosati, Dezirae Schneider, and Anne Wiedmer for help with the highthroughput assays. Insightful advice about programming in R software was provided by Reto Guadagnini.

\section{Funding}

This study was supported by a Candoc grant (FK-19-025) of the University of Zurich to ADM and by grants of the Swiss Personalised Health Network (SPHN, driver project grant 2017DRI17), Swiss National Foundation (SNF 179040), the European Research Council (ERC Prion2020, 670958) and the Nomis Foundation to AA. 
medRxiv preprint doi: https://doi.org/10.1101/2021.11.24.21266833; this version posted November 26, 2021. The copyright holder for this preprint (which was not certified by peer review) is the author/funder, who has granted medRxiv a license to display the preprint in It is made available under a CC-BY-NC 4.0 International license.

\section{Conflict of interest}

All authors have completed the ICMJE uniform disclosure form at www.icmje.org/coi disclosure.pdf and declare: ADM has received a research grant from University of Zurich; KF has received research grants from Ono Pharmaceuticals and Theodor Ida Herzog Egli Stiftung, consulting fees from Acumen Collective and Ionis Pharmaceuticals, support for attending meetings/travel from Euro-CNS and has participated on the Advisory Board of Mabylon AG; AA has received research grants from the Swiss Personalised Health Network, Swiss National Foundation, European Research Council and Nomis Foundation and is a member of the Board of Directors of Mabylon AG. Mabylon AG produces therapeutic human antibodies. Mabylon AG had no insight and no influence on the current study. All authors report no other relationships or activities that could appear to have influenced the submitted work.

\section{Author contributions}

Conceived and designed the experiments: ADM, SH, AA. Supervised the study: SH, AA. Performed tau protein purification: ADM, EDC. Performed tau microELISA automated screen: ADM, ME. Performed amyloid- $ß$ pyroglutamate and cellular prion protein microELISA automated screen: MC, KF, ME. Maintained microELISA automated platform: ME. Performed purification, validation and characterization of anti-tau autoantibodies: ADM. Maintained the clinical database: ME, AC. Performed data analysis and visualization: ADM. Wrote the first draft of manuscript: ADM. Corrected and advised on subsequent versions of the manuscript: ADM, ME, SH, AA. All authors reviewed and approved the final version of the manuscript and consented to be accountable for the work. 
medRxiv preprint doi: https://doi.org/10.1101/2021.11.24.21266833; this version posted November 26, 2021. The copyright holder for this preprint (which was not certified by peer review) is the author/funder, who has granted medRxiv a license to display the preprint in It is made available under a CC-BY-NC 4.0 International license .

\section{Figure Legends}

Figure 1. Study overview and validation of positive samples. A. Flow diagram of the patient samples included in the study. B. Distribution of the $-\log _{10}\left(E C_{50}\right)$ values obtained from the microELISA screen of the university hospital patient samples. C. Same as (B), but for the healthy blood donor samples. D. Age-and-sex adjusted risk ratio ratios and $95 \%$ confidence intervals ( $\mathrm{Cl}$; I bars) for the detection of anti-tau autoantibodies in university hospital patients' and healthy blood donors' samples. Pos. $\mathrm{n}^{\circ}$ : number of positive samples with the respective characteristic. Total $n^{\circ}$ : total number of samples. E. Assessment of replicability by testing samples in duplicates with independent estimation of the $-\log _{10}\left(E_{50}\right)$ values. Dashed lines indicate the $-\log _{10}\left(E C_{50}\right)$ cut-off value of 1.8. F. $-\log _{10}\left(E C_{50}\right)$ values of samples tested in the microELISA screen against MTBD-tau and amyloid-ß pyroglutamate. G. Same as shown in (F), but for samples tested against MTBD-tau and the cellular prion protein ( $\operatorname{Pr} \mathrm{P}^{\mathrm{C}}$ ).

Figure 2. Validation of anti-tau autoantibodies. A. Competition ELISA of purified anti-tau autoantibodies from four different $\tau^{+}$patients. B. Indirect ELISA to assess the specificity of the purified anti-tau autoantibodies against MTBD-tau. C. Immunocytochemical analysis of EGFPtauON4R transfected SH-SY5Y cells using affinity-purified anti-tau autoantibodies. Scale bar: $60 \mu \mathrm{m}$. D. Western blot analysis of cells lysates of tau-expressing SH-SY5Y cells using affinitypurified anti-tau autoantibodies from four different $\tau^{+}$.

Figure 3. Demographic characteristics of samples. A. Age and sex pyramid for the positive and negative populations. Negative samples/10 are shown in darker color and positive samples are shown in lighter color. B. Distribution of the percentage of positives in 10 yearage groups. The numbers on top of each bar correspond to the positivity rates and the numbers inside the bars show the number of positives in the age group above the number of tested samples in the same age group. The $P$ value is shown for the test of equality of proportions. C. Risk ratios and 95\% confidence intervals ( $\mathrm{Cl}$; I bars) for the detection of antitau autoantibodies in plasma samples of patients according to sex and age groups. D. Distribution of samples by the different hospital department of origin. Negative samples/10 are shown in dark purple and positive samples in light purple. $* p<0.050$. E. Age-and-sex adjusted risk ratio ratios and $95 \%$ confidence intervals $(\mathrm{Cl} ; \mathrm{I}$ bars) for the detection of tau autoantibodies in plasma samples of patients according to the hospital department of origin. 
medRxiv preprint doi: https://doi.org/10.1101/2021.11.24.21266833; this version posted November 26,2021 . The copyright holder for this preprint (which was not certified by peer review) is the author/funder, who has granted medRxiv a license to display the preprint in It is made available under a CC-BY-NC 4.0 International license .

Figure 4. Risk ratio of detectable tau autoantibodies for neurological disorders and reactivity profiles for AD screen. A. Age-and-sex adjusted risk ratios and $95 \%$ confidence intervals ( $\mathrm{Cl}$; I bars) for the detection of tau autoantibodies in plasma samples of patients according to different groups of neurological disorders. P values are Bonferroni corrected. B. Waterfall plots demonstrating the reactivity profiles in the $A D$ patients and controls screen. C. Boxplots showing the $25^{\text {th }}, 50^{\text {th }}$ (median) and $75^{\text {th }}$ percentiles of the reactivity profiles for $A D$ and control patients. Comparison of groups was done using Mann-Whitney $U$ test.

Figure 5. Risk ratio of detectable tau autoantibodies for systemic clinical conditions. A. Ageand-sex adjusted risk ratios and 95\% confidence intervals ( $\mathrm{Cl}$; I bars) for the detection of tau autoantibodies in plasma samples of patients according to ICD-10 codes for the diagnosis of 14 different main systemic clinical conditions. P values are Bonferroni corrected. B. Same as (A), but according to individual disease entities from significant main systemic disease groups. Predictors from individual disease entities analysis shown in Figure $\mathrm{S} 4$ with $\mathrm{P}<0.05$ corrected for multiple comparisons were included in this multivariate log-binomial regression analysis. The $\mathrm{P}$ value was derived from the multivariate model.

Figure 6. Risk ratio of detectable tau autoantibodies for laboratory parameters. A. and B. Age-and-sex adjusted risk ratios and 95\% confidence intervals ( $\mathrm{Cl}$; I bars) for the detection of tau autoantibodies in plasma samples of patients according to (A) relevant clinical laboratory parameters and (B) chronic kidney disease defined as the presence of the estimated glomerular filtration rate (eGFR) $\left(<60 \mathrm{~mL} / \mathrm{min} / 1.73 \mathrm{~m}^{2}\right.$ for at least 3 months; Chronic Kidney Disease [CKD] Epidemiology Collaboration 2009 formula). P values are Bonferroni corrected. UNL: upper limit of normal range. LNL: lower limit of normal range. HbA1c: glycated hemoglobin. LDL: low-density lipoprotein. HDL: high-density lipoprotein. C. Distribution of the $-\log _{10}\left(E C_{50}\right)$ of patients classified as having chronic kidney disease $\left(e G F R<60 \mathrm{~mL} / \mathrm{min} / 1.73 \mathrm{~m}^{2}\right)$, and classified as not having chronic kidney disease (eGFR>60). D. Boxplots showing the $25^{\text {th }}$, $50^{\text {th }}$ (median) and $75^{\text {th }}$ percentiles of the difference between the last eGFR measured before the screen and the most recent eGFR measurement available for patients with a high-titer (positive) and a low-titer of anti-tau autoantibodies (negative). Comparison of groups was done using Mann-Whitney U test. 
A

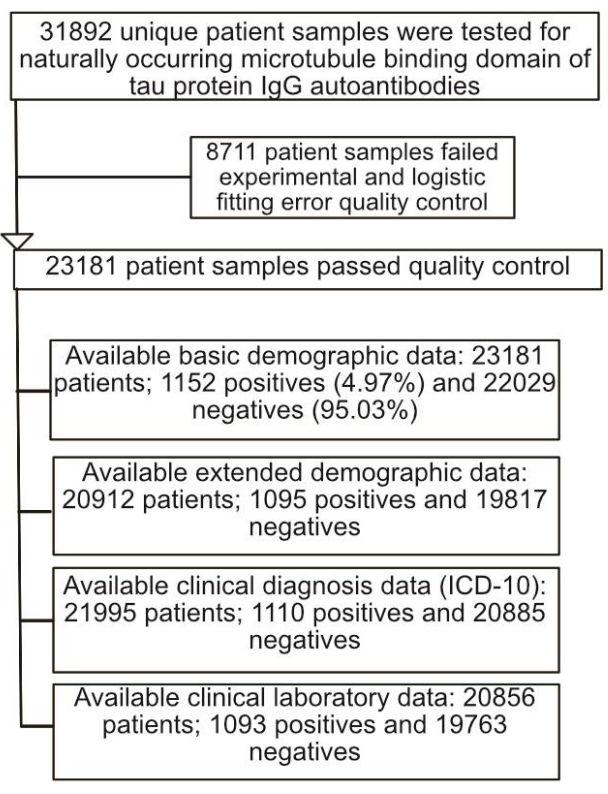

E

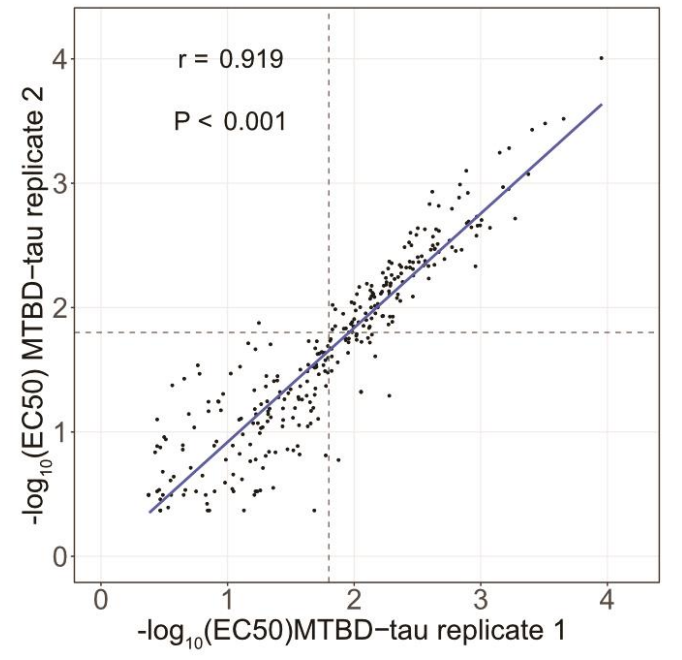

B

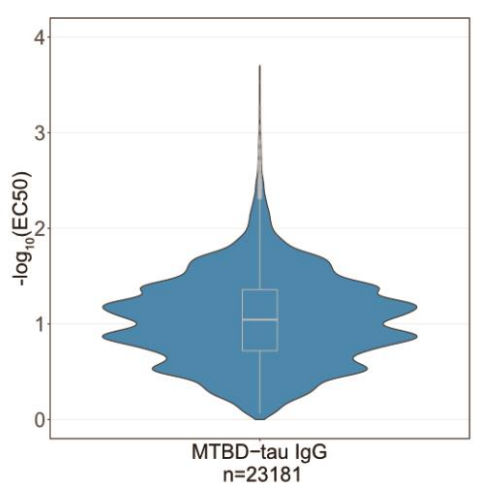

D

Characteristic

\section{Prevalence \\ pos. $n^{\circ} /$ total $n^{\circ}(\%)$}

Hospital patient $\quad 1152 / 23181(4.97)$

Healthy donor

$77 / 4157$ (1.85)

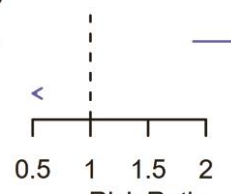

$\begin{array}{llll}0.5 & 1 & 1.5 & 2 \\ & \text { Risk Ratio }\end{array}$

F

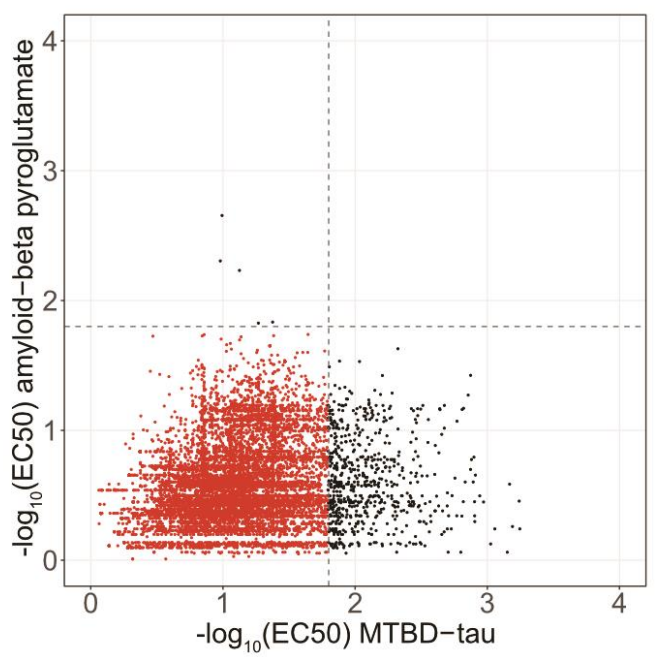

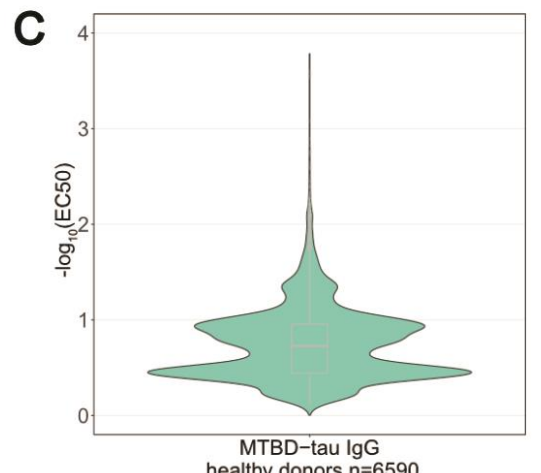

Risk Ratio $(95 \%$ Cl) P value

$2.37(1.89-3.02) \quad<0.001$

$0.42(0.33-0.53)$

G

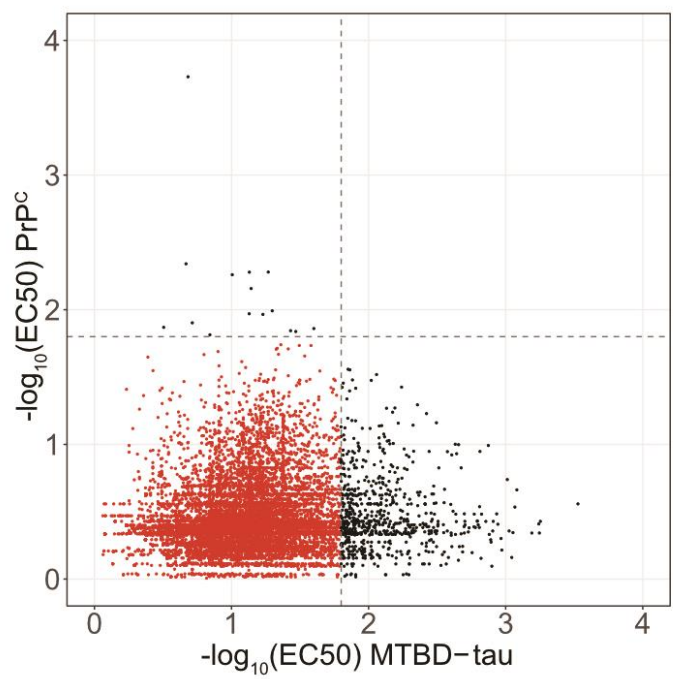

Magalhães et al, Figure 1 
A
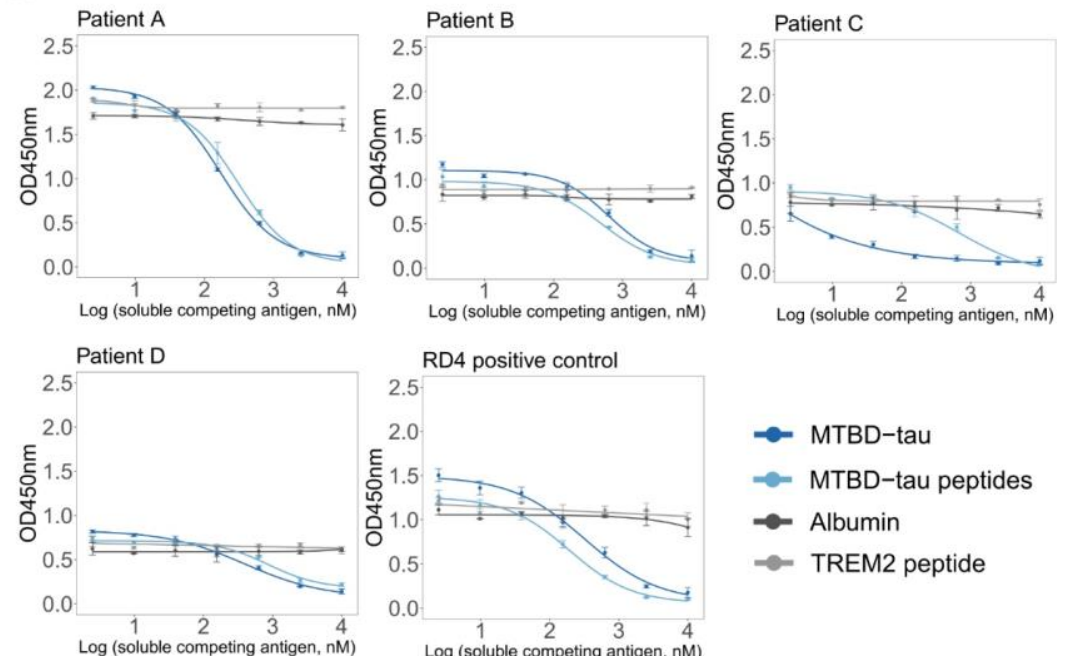

- MTBD-tau

$\rightarrow$ MTBD-tau peptides

$\rightarrow$ Albumin

$\rightarrow$ TREM2 peptide

B
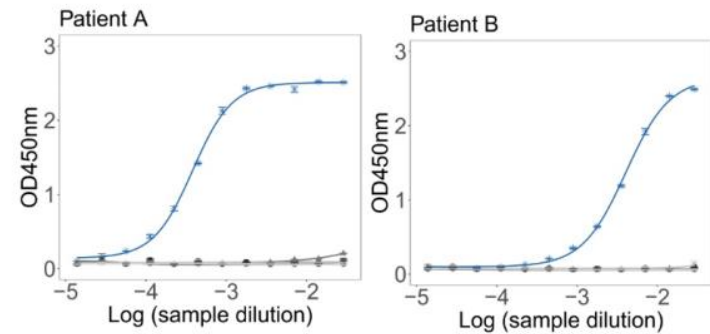

Patient C
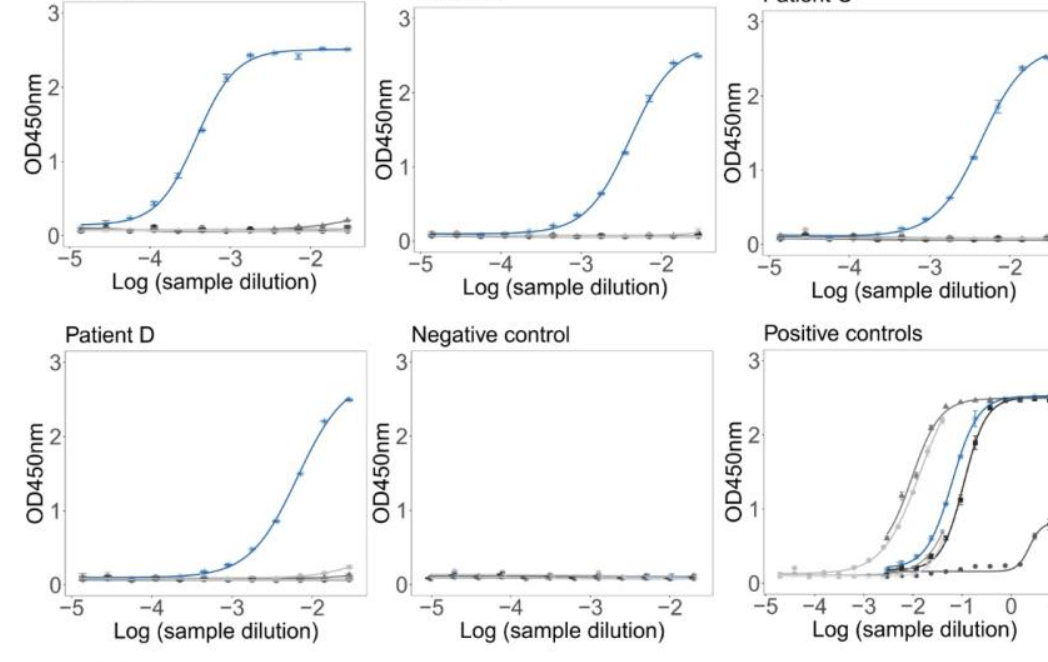
Negative control Positive controls

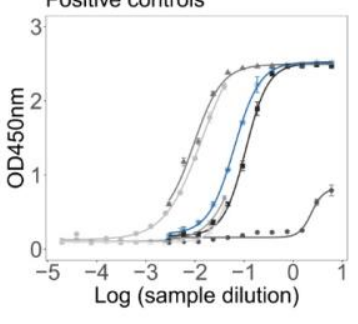

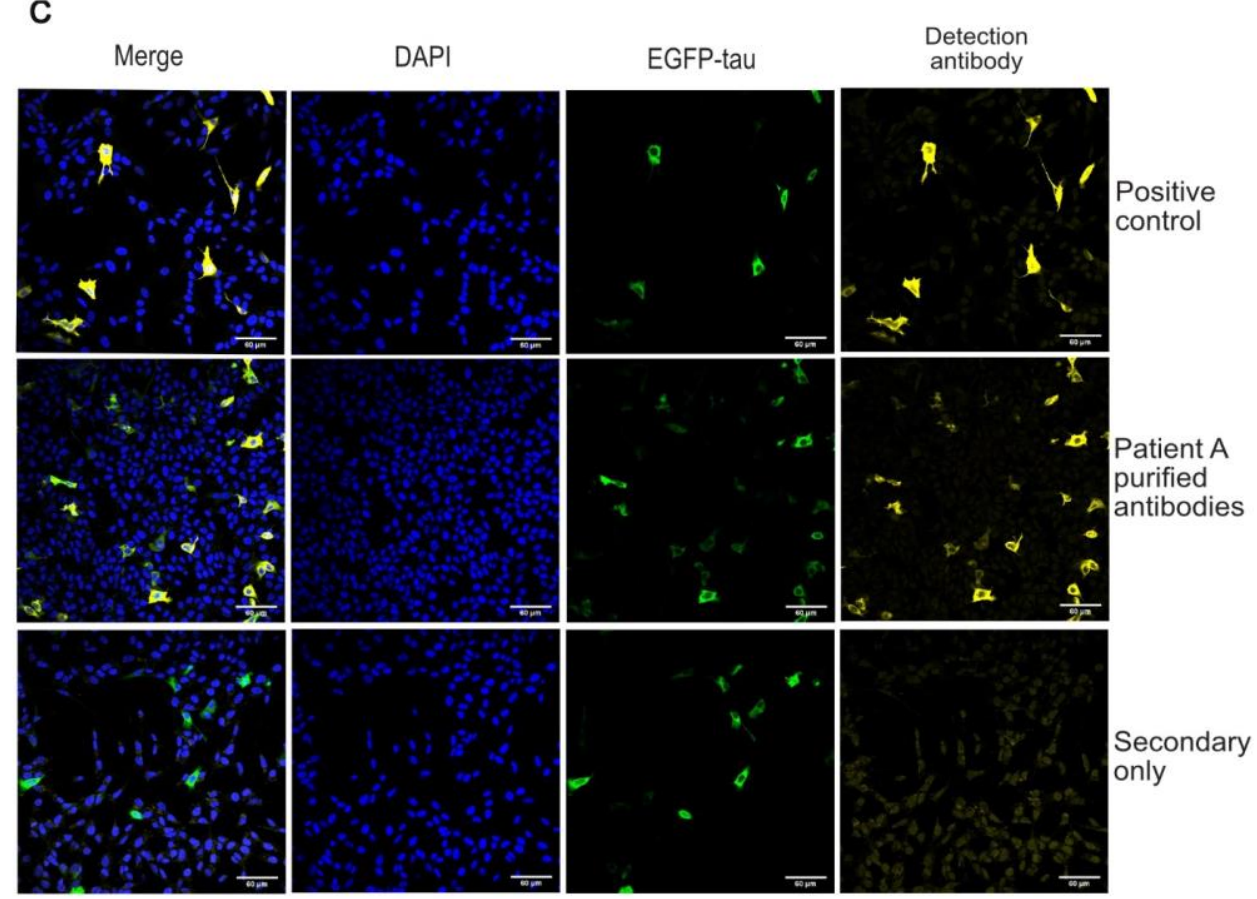

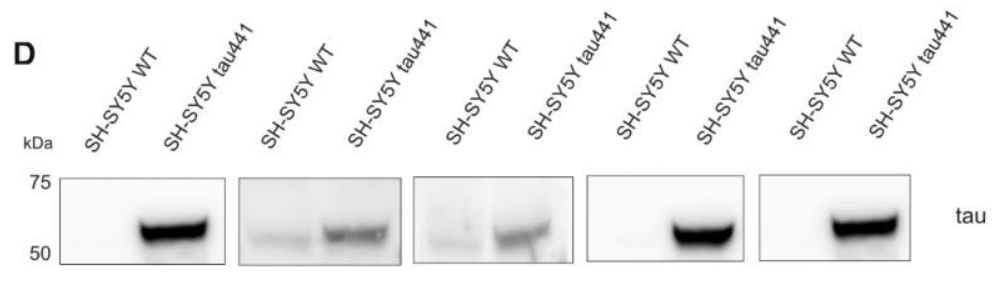

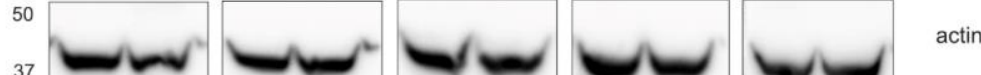

Patient A

Patient B

Patient C

Patient D

Magalhães et al, Figure 2 
A

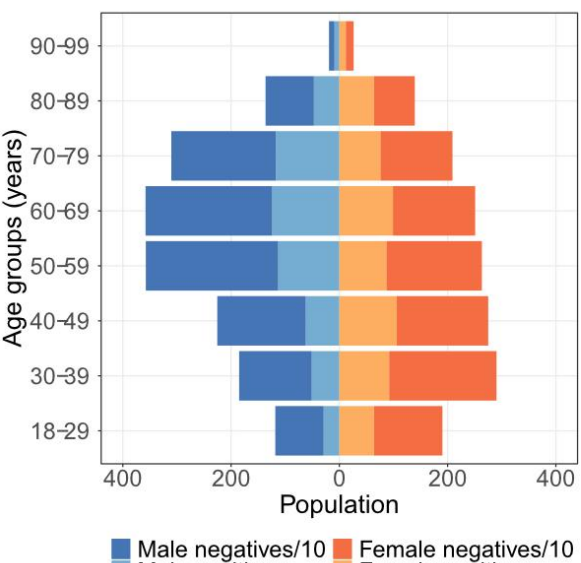

$\begin{array}{lll}\begin{array}{ll}\text { Male negatives/10 } \\ \text { Male positives }\end{array} & \text { Female negatives/10 } \\ \text { Female positives }\end{array}$

C

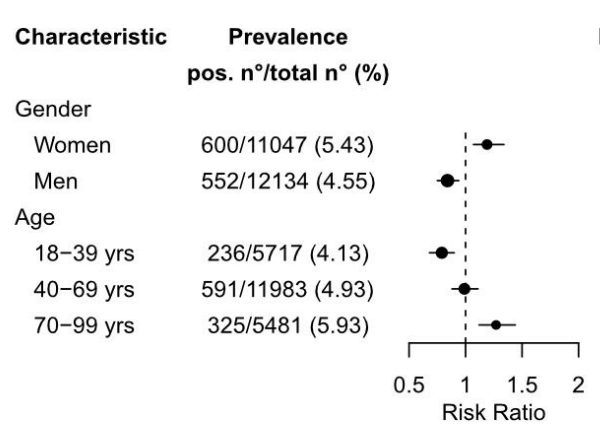

E

Characteristic

Department of Origin

Nephrology

Obstetrics
B

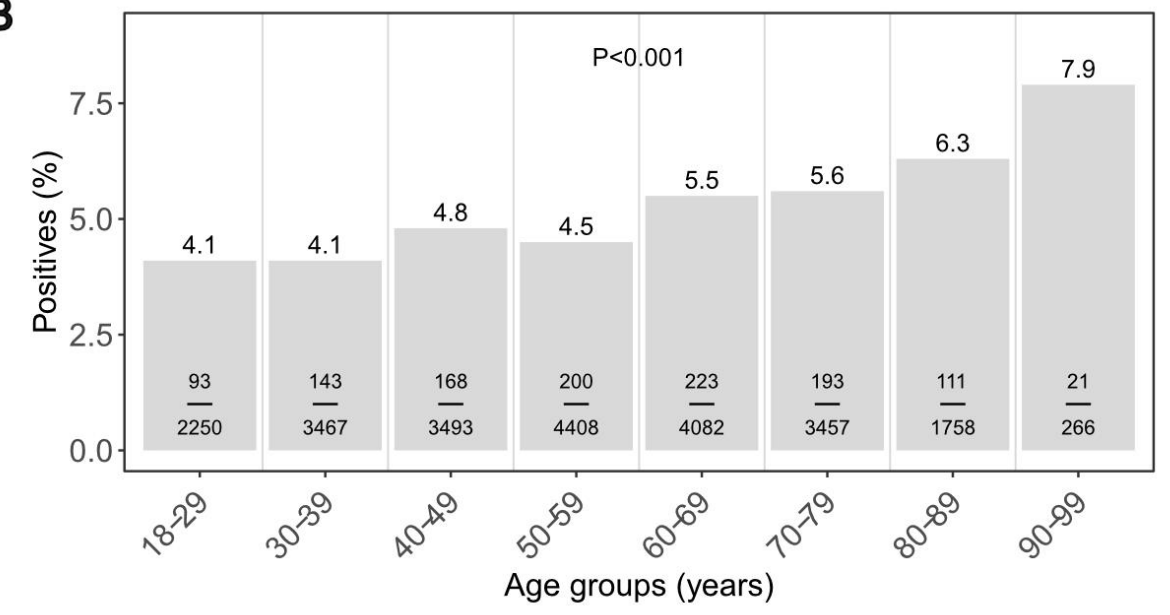

D

Risk Ratio $(95 \% \mathrm{Cl}) \quad \mathrm{P}$ value

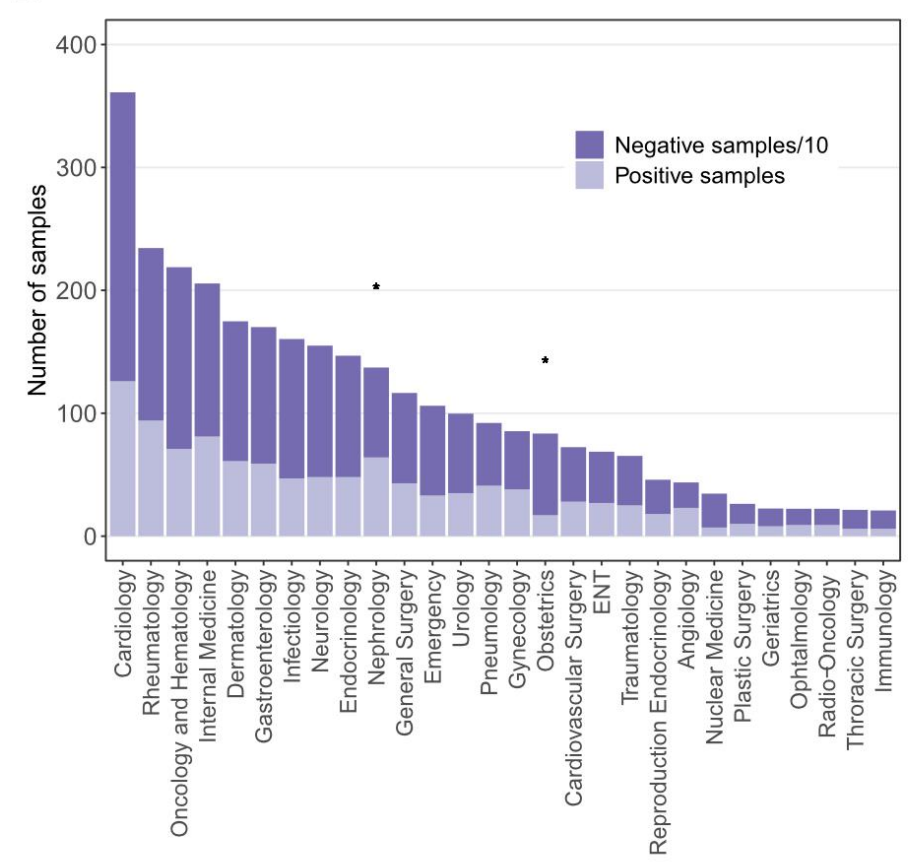

Magalhães et al, Figure 3 
medRxiv preprint doi: https://doi.org/10.1101/2021.11.24.21266833; this version posted November 26, 2021. The copyright holder for this preprint (which was not certified by peer review) is the author/funder, who has granted medRxiv a license to display the preprint in

perpetuity.
It is made available under a CC-BY-NC 4.0 International license.

A

Disorder

Extrapyramidal and movement disorders

Sleep disorders

Headache disorders

Dementia

Neuropathies

Stroke

Traumatic brain injury

Demyelinating diseases of the CNS

Epilepsy

Diseases of myoneural junction

Myopathies

Inflammatory/Infectious diseases of the CNS
Prevalence

pos. $n^{\circ} /$ total $n^{\circ}(\%)$

$15 / 205(7.32)$

$53 / 832(6.37)$

$41 / 682(6.01)$

$6 / 84(7.14)$

$78 / 1414$ (5.52)

$58 / 1077$ (5.39)

$52 / 1038(5.01)$

$12 / 280$ (4.29)

$39 / 864$ (4.51)

$3 / 74(4.05)$

6/193 (3.11)

$3 / 148(2.03)$

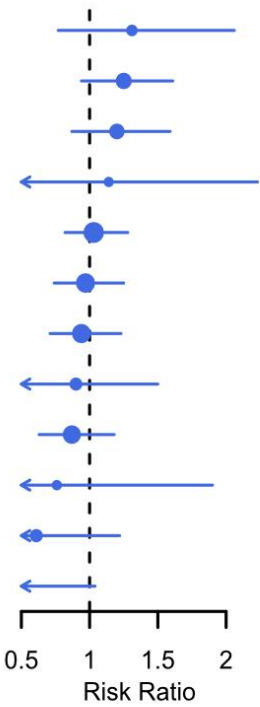

Adjusted P value

Risk Ratio (95\% Cl)

$1.31(0.77-2.06)$

$1.25(0.94-1.61) \quad 1$

$1.20(0.87-1.59) \quad 1$

$1.14(0.46-2.23) \quad 1$

$1.03(0.82-1.28) \quad 1$

$0.97(0.74-1.25) \quad 1$

$0.94(0.71-1.23) \quad 1$

$0.90(0.49-1.50) \quad 1$

$0.87(0.63-1.18) \quad 1$

$0.76(0.19-1.90) \quad 1$

$0.61(0.24-1.22) \quad 1$

$0.41(0.10-1.04) \quad 1$

B
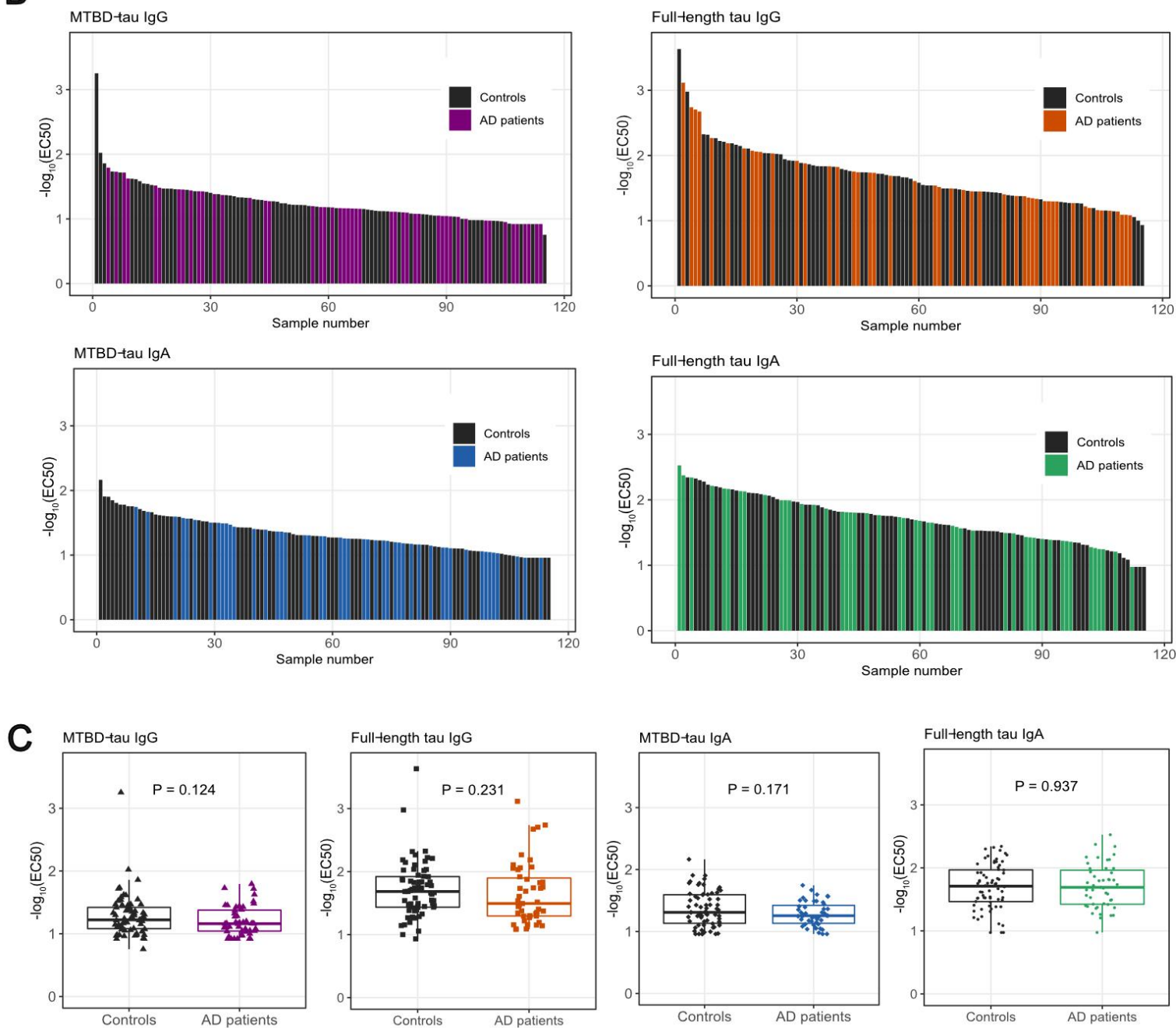

Magalhães et al, Figure 4 
medRxiv preprint doi: https://doi.org/10.1101/2021.11.24.21266833; this version posted November $26,2021$. The copyright holder for this preprint (which was not certified by peer review) is the author/funder, who has granted medRxiv a license to display the preprint in

It is made available under a CC-BY-NC 4.0 International license .

A

Group of Disorders

Prevalence

pos. $n^{\circ} /$ total $n^{\circ}(\%)$

Peripheral vascular disorders

Tobacco use

Kidney disease

Diabetes

Obesity

Congestive heart failure

Liver disease

Hypertension

Alcohol abuse

Chronic pulmonary disease

Malignant disease

Ischemic heart disease

Metastatic malignant disease

AIDS/HIV
$175 / 2422(7.23)$
$54 / 789(6.84)$
$211 / 3117(6.77)$
$166 / 2544$ (6.53)
102/1551 (6.58)
$141 / 2285(6.17)$
$88 / 1520$ (5.79)
$374 / 6230(6)$
46/862 (5.34)
$88 / 1629(5.4)$
237/4461 (5.31)
$67 / 1285$ (5.21)
$82 / 1628$ (5.04)
$15 / 380$ (3.95)

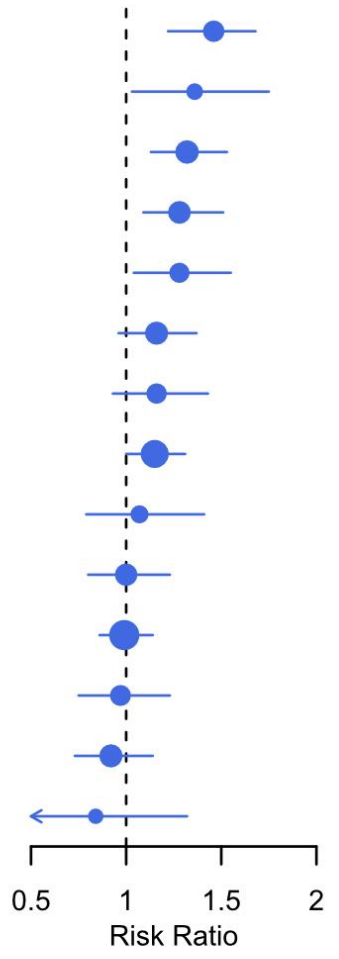

Adjusted Pvalue

Risk Ratio $(95 \% \mathrm{Cl})$

$1.46(1.22-1.68) \quad<0.001$

$1.36(1.03-1.75) \quad 0.335$

$1.32(1.13-1.53) \quad 0.004$

$1.28(1.09-1.51) \quad 0.038$

$1.28(1.04-1.55) \quad 0.192$

$1.16(0.96-1.37) \quad 1$

$1.16(0.93-1.43) \quad 1$

$1.15(1-1.31) \quad 0.664$

$1.07(0.79-1.41) \quad 1$

$1(0.8-1.23) \quad 1$

$0.99(0.86-1.14) \quad 1$

$0.97(0.75-1.23) \quad 1$

$0.92(0.73-1.14)$

$0.84(0.48-1.32)$

B

Disorder

Cystitis

Arterial embolism and thrombosis

Atherosclerosis

Sex, female

Other urinary system disorders

Chronic kidney disease

Age, year
Prevalence

pos. $n^{\circ} /$ total $n^{\circ}(\%)$

$37 / 370$ (10)

25/240 (10.42)

$115 / 1396$ (8.24)

$585 / 10588$ (5.53)

$168 / 2348$ (7.16)

$198 / 2815(7.03)$

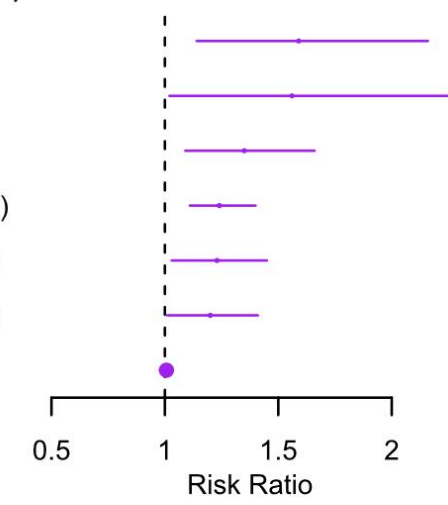

Adjusted

$P$ value

Risk Ratio $(95 \% \mathrm{Cl})$

$1.59(1.14-2.16) \quad 0.004$

$1.56(1.02-2.25) \quad 0.026$

$1.35(1.09-1.66) \quad 0.004$

$1.24(1.11-1.40) \quad<0.001$

$1.23(1.03-1.45) \quad 0.018$

$1.20(1.01-1.41) \quad 0.033$

$1.007(1.003-1.01) \quad<0.001$

Magalhães et al, Figure 5 
A

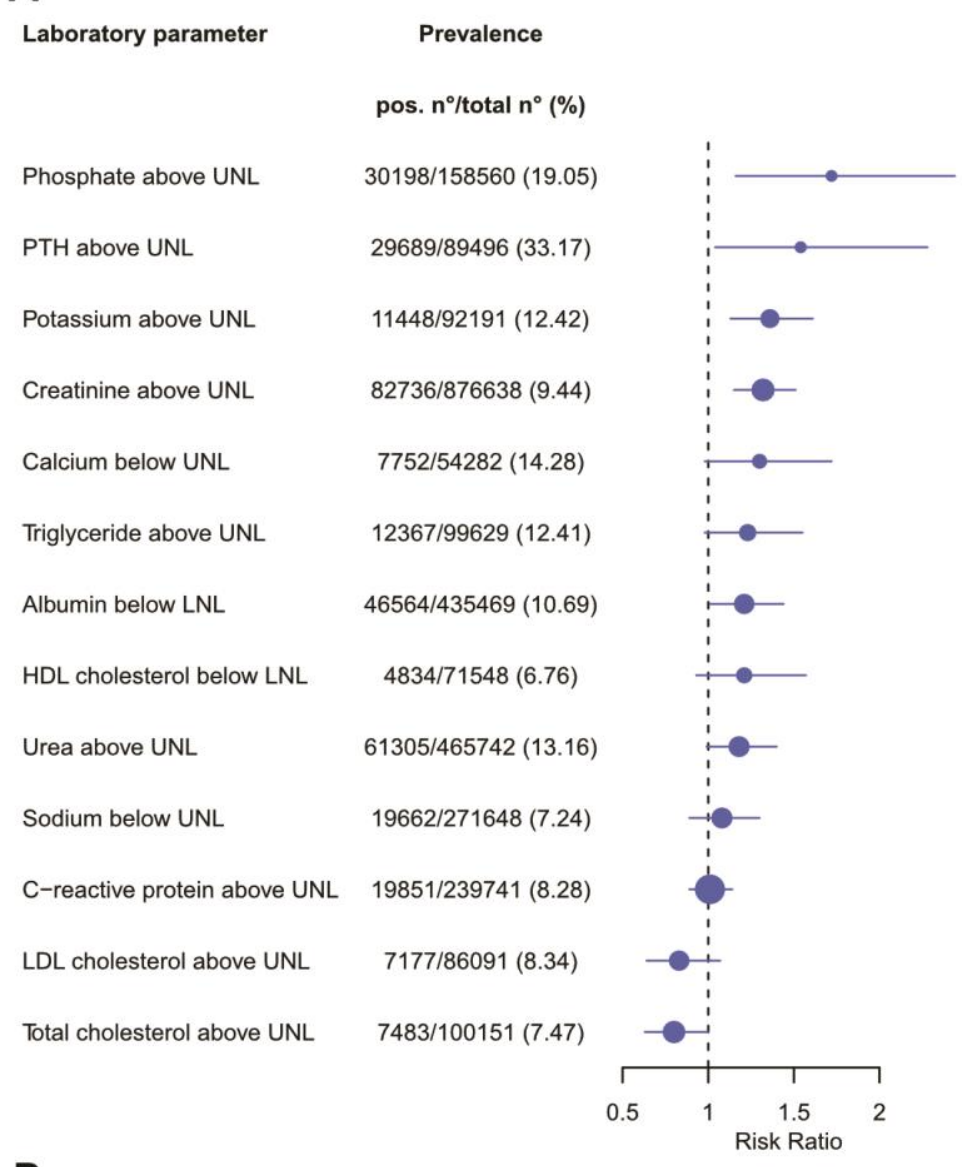

Adjusted Pvalue

Risk Ratio $(95 \% \mathrm{CI})$

$1.72(1.16-2.44) \quad 0.053$

$1.54(1.04-2.28) \quad 0.377$

$1.36(1.13-1.61) \quad 0.010$

$1.32(1.15-1.51) \quad<0.001$

$1.30(0.98-1.72) \quad 0.857$

$1.23(0.98-1.55) \quad 0.943$

$1.21(1.01-1.44) \quad 0.436$

$1.21(0.93-1.57)$

$1.18(0.99-1.40) \quad 0.772$

$1.08(0.89-1.30)$

$1.01(0.89-1.14)$

$0.83(0.64-1.07)$

$0.80(0.63-1.00)$

0.742
B

Disease

\section{Prevalence}

pos. $n^{\circ} /$ total $n^{\circ}(\%)$

Chronic kidney disease
Adjusted P value

Risk Ratio $(95 \% \mathrm{Cl})$

$1.38(1.09-1.72) \quad 0.005$
C

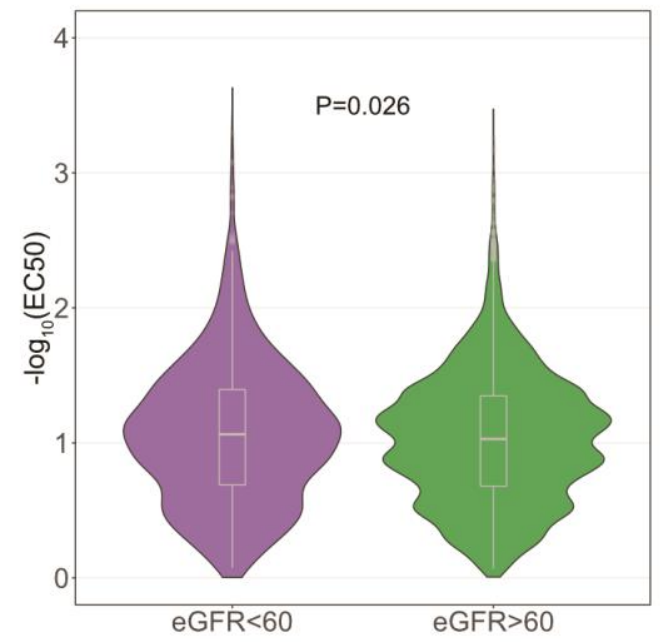

D

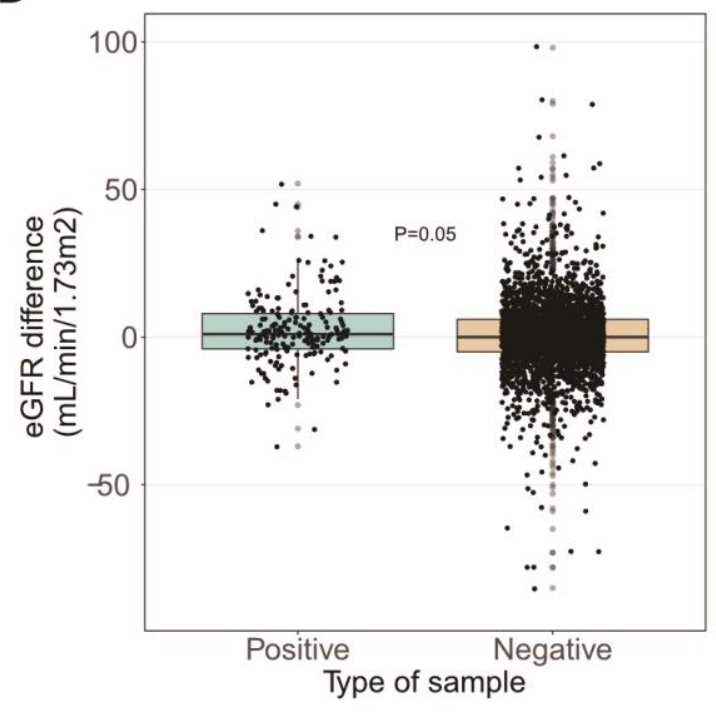

Magalhães et al, Figure 6 
medRxiv preprint doi: https://doi.org/10.1101/2021.11.24.21266833; this version posted November 26, 2021. The copyright holder for this preprint (which was not certified by peer review) is the author/funder, who has granted medRxiv a license to display the preprint in It is made available under a CC-BY-NC 4.0 International license . 